\title{
Duty Drawbacks, Competitiveness and Growth: Are Duty Drawbacks Worth the Hassle?
}

\author{
Elena Ianchovichina* \\ The World Bank
}

\begin{abstract}
Many countries use duty drawbacks on exports, yet they have been given little attention in the literature and there is no consensus whether countries should embrace or abandon them. This paper asserts that the answer depends on a country's development priorities and economic conditions. An increase in the drawback has a positive impact on export competitiveness and employment, but could lead to exports with low domestic value added. The welfare effects of duty drawback reform are ambiguous. An increase in the drawback is more likely to be welfare improving if the economy is small with high input tariffs, low initial drawback, low administrative costs and leakages in the tariff collection system. In China duty drawback removal after meeting its WTO commitments will deepen domestic supply chains and improve welfare, but will hurt China's economic efficiency, export competitiveness and real factor incomes. Further liberalization could mitigate these negative effects.
\end{abstract}

Keyword: Duty drawback; Competitiveness; Tariff reform; China;

JEL classification: F11; F13

World Bank Policy Research Working Paper 3498, February 2005

The Policy Research Working Paper Series disseminates the findings of work in progress to encourage the exchange of ideas about development issues. An objective of the series is to get the findings out quickly, even if the presentations are less than fully polished. The papers carry the names of the authors and should be cited accordingly. The findings, interpretations, and conclusions expressed in this paper are entirely those of the authors. They do not necessarily represent the view of the World Bank, its Executive Directors, or the countries they represent. Policy Research Working Papers are available online at http://econ.worldbank.org.

\footnotetext{
* The author is Senior Economist with the Economic Policy Department, PREM Network, The World Bank, 1818 H Street, NW, Washington DC 20433; email eianchovichina@,worldbank.org. This paper has not undergone the review accorded to official World Bank publications. The author thanks William Martin and Deepak Bhattasali for encouraging this work and Li Yan from Customs General Administration, People's Republic of China, for her advice and data on export processing arrangements and trade. The author appreciates comments from Marcelo Olarreaga, Mary Amiti, William Martin, Deepak Bhattasali and Bernard Hoekman.
} 


\section{Executive Summary}

Many countries use duty drawbacks on exports, yet they have been given relatively little attention in the literature and there is no consensus whether countries should embrace or abandon them. This paper asserts that the answer depends on the country's development priorities and economic conditions. An increase in the duty drawback has a positive impact on export competitiveness and employment in the export-oriented industries, but could lead to exports with low domestic value added. The welfare effects of duty drawback and trade reform in the presence of a drawback are ambiguous in general. An increase in the drawback is more likely to enhance welfare if the economy is small with high input tariffs and intensity of imported input use in the export-oriented sectors, low initial drawback, low administrative costs and leakages in the tariff collection system. In such an economy liberalizing intermediate good markets can be welfare enhancing if the cost share of the imported input is higher in the export-processing than in the import-competing sector. This is more likely to be true for a lower duty drawback and higher intensity of import use in the export-oriented sector. If there is a complete duty drawback, liberalizing intermediate input markets is unambiguously welfare reducing. In China duty drawback removal after meeting its WTO commitments will deepen domestic supply chains and improve welfare, but will hurt China's economic efficiency, output growth, export competitiveness in key manufacturing industries and real factor incomes. Further liberalization could mitigate the negative effects. 


\section{Introduction}

Economic theory traditionally considers trade liberalization to be the reduction or complete removal of existing trade restrictions and economists typically endorse it as a 'first-best' type of trade liberalization. While removal of existing trade barriers is the most direct way to free trade, many economies have chosen more gradual and flexible approaches. These involve 'concessional' trade liberalization instruments including intra-industry liberalization via duty drawback schemes, sub-national liberalization through the development of export processing zones (EPZs), firm-specific liberalization by negotiating import rights with individual firms or expanding eligibility for import permits, and regional trade liberalization by forming regional free trade blocs.

This paper focuses on one type of 'concenssional' trade instruments - duty drawbacks (or rebates). ${ }^{1}$ These reduce or eliminate the duties paid on imported intermediates or raw materials used in the production of exports. A firm importing an intermediate product for use in the production of an export good is either exempt from the tariff payments on the imported input (duty exemption system) or gets a refund of the tariff payments made once the final product is exported (rebate or duty drawback system).

Duty drawbacks have been popular as an indirect tax incentive for foreign direct investment and an instrument to reduce the anti-export bias of otherwise highly protected economies. $^{2,3}$ Despite their wide use, duty drawbacks have been given relatively little

\footnotetext{
${ }^{1}$ In this paper we abstract from the administrative aspects of obtaining a refund and use the term duty drawback to refer to both drawbacks and exemptions. The important point is that any tariff payments for imported inputs get back to the producer if the final product is exported. Wu and Chuang (1998) describe in detail the functioning of the duty drawback systems in Taiwan (China) and Costa Rica.

${ }^{2}$ Full duty drawbacks reduce, but do not completely eliminate the anti-export bias, since tariffs on final goods continue to provide positive effective protection to the domestic-oriented sectors.

${ }_{3}^{3}$ Duty drawbacks have been popular in both developed and developing countries (see International Monetary Fund, 2002). Michalopoulos (1999) finds that all but three economies (Benin, Singapore and Hong Kong) in a sample of 42 developing economies have in place some form of duty drawbacks. However, some economies have used duty drawbacks with more success than others. For instance, most East Asian
} 
attention in the literature. ${ }^{4}$ Herander (1986) was among the first to study the implications of duty drawbacks for the structure of protection. ${ }^{5}$ Using the standard framework for the analysis of effective protection ${ }^{6}$ and assuming that foreign and domestic goods are perfect substitutes, he identifies the conditions determining whether domestic component producers or domestic final good consumers will bear the costs of export expansion following the introduction of duty drawbacks. He finds that when domestic final good consumption is low relative to domestic component production, domestic component producers are worse off, while domestic consumers are better off with duty drawbacks. When domestic final good consumption is high relative to domestic component production, domestic component producers retain their protection while consumers face a higher price if duty drawbacks are coupled with a large final good import tariff. This results in a protection structure of escalating tariffs, which is typical for many countries. ${ }^{7}$ Conversely, domestic component producers lose, while domestic final good consumers benefit if final good tariffs are lowered or completely eliminated. This results in a protection structure of de-escalating tariffs and the emergence of two-way trade.

Panagariya (1992) analyzed the welfare implications of trade reform in the presence of duty drawbacks in a small open economy with perfectly competitive markets.

economies have used duty drawback schemes effectively, whereas in many African countries poor execution of such schemes has led to very few benefits for exporters (Hinkle et al. 2003).

${ }^{4}$ In January 2004 the 'ECONLIT' database contained 5 articles on duty drawbacks, 1 on export drawbacks and 1 on export linkages. Considerably more attention has been given to exploring the implications of different kinds of protectionism including voluntary export restraints (VERs), 'strategic' trade interventions, and more recently to EPZs. The ECONLIT database contained 133 references to 'voluntary export restraints', 324 to 'strategic trade' and 48 to 'export processing zones'.

${ }^{5}$ Balassa et al. (1970) discussed in detail the duty drawback policies of several developing countries, while Hufbauer and Erb (1984) surveyed such policies in developed countries.

${ }^{6}$ The standard framework for the analysis of effective protection assumes a fixed coefficient, two-stage production process (component production and final good assembly), upward sloping supply curve for factors (value added) and intermediate inputs (components), perfectly competitive markets, exogenous world prices of components and final goods.

${ }^{7}$ World Bank data at www.worldbank.org/trade indicate that 48 out of 86 economies had escalating tariffs on industrial products between 1994 and 2000. One country (Bolivia) had de-escalating tariffs and the rest had a mix of increasing and decreasing tariff rates from one stage to another. 
He arrived at three broad conclusions in the case when goods are substitutes in consumption and production, and there is no two-way trade in the good intended for exports. An increase in the duty drawback, when none has been in place in the initial equilibrium, is welfare improving up to a point. Increases in tariffs on inputs complemented by full duty drawbacks are welfare improving up to a point. Tariffs on inputs unaccompanied by duty drawbacks on exports have an ambiguous effect on welfare.

In more recent years economists have focused their attention on duty drawbacks and the speed of trade liberalization. In general there is no agreement on this issue. Gruen (1999) argues that 'concessional' trade liberalization instruments enable the trade liberalization path to be specified in a flexible way ensuring targeted and gradual trade reform, which may not be possible using traditional tariff dismantling. ${ }^{8}$ Cadot et al. (2003) however show that in a political-economy setting, where tariffs and duty drawbacks are endogenously chosen through industry lobbying, full duty drawbacks granted to exporters slow down trade liberalization since they decrease exporters' incentives to counter-lobby against high tariffs on their inputs.

There is also no consensus whether countries should embrace duty drawbacks or whether and when they should abandon them. In the past the World Bank recommended in their loans the creation or improvements of duty drawback and temporary admission regimes (Krueger and Rajapatirana, 1999). A World Bank study by Thomas et al. (1991) also made a strong case in favor of duty drawbacks as instruments of export promotion when there is import protection. But more recently the IMF (International Monetary Fund, 2002) warns against the use of duty drawbacks and other indirect tax incentives since they

\footnotetext{
${ }^{8}$ The political economy climate in a country is an important reason for choosing a duty drawback scheme over liberalization. In China, for instance, the government could never have gotten a full free trade regime in the late seventies, but it could get an agreement to liberalize tariffs on imports used in the production of exports.
} 
can lead to abuses, are difficult to justify on policy grounds and offer second best solutions. $^{9}$

Earlier studies conducted their analysis at the aggregate level producing few indicators that can guide policy discussions at the industry level. We address this gap in the literature by analyzing not only the welfare outcome, but the economic and industry-level impacts of duty drawback and trade reform in the presence of domestic distortions. Using a modified á la Panagariya (1992) model we first study the welfare implications of duty drawback and trade reform. Unlike Panagariya (1992) we do not restrict the analysis to a small open economy. The small country assumption simplifies the analysis, ${ }^{10}$ but may not be appropriate for some countries. The welfare analysis improves over previous work by taking into account domestic tax distortions, ${ }^{11}$ and extending the analysis beyond reform of input tariffs and duty drawbacks. We also depart from the standard representation of a single sector involved in two types of activities - producing for domestic and export markets, and instead distinguish between two sectors specialized in two types of activities - one sector produces only exports, the other produces only for the domestic market. This separation is preferable to representations based on a single sector because it allows the

\footnotetext{
${ }^{9}$ Acknowledging the common use of duty drawbacks worldwide as an export and foreign investment incentive, the IMF concludes that tariff drawbacks should be used only for export purposes (much of the economists' skepticism about duty exemptions is about exemptions not related to exports) and that countries with weak customs and tax administrations should choose duty rebates instead of exemptions in order to minimize the risk of tariff leakages. However, evidence suggests that exporters in many countries with rebate schemes have found it difficult to collect refunds. Uncertainties of payment and delays of up to a year in the reimbursement of import duties were major problems, for instance, in Uganda (1996), South Africa (1996), Tanzania (1996) and Zimbabwe (1998) (Hinkle et al. 2003). These delays render the drawbacks schemes ineffective.

${ }^{10}$ The small economy assumption implies that the country is a price taker and domestic reforms will not affect world prices so that they can be fixed at 1 .

${ }^{11}$ Omitting domestic tax distortions from the analysis of trade reform may bias its conclusions (Konan and Maskus, 2000). First, in a second-best world reductions in trade barriers could raise or lower the marginal excess burden of the existing tax structure. Second, as governments lose revenues from liberalization, they may be forced to raise domestic tax rates in compensation.
} 
two sectors to use different input mixes, and the export-oriented activities to use much more import-intensive means of production (Ianchovichina, 2004).

We then undertake an empirical evaluation of the economic effects of duty drawback and trade reform using a multi-country, multi-sector general equilibrium model. We assess the impacts of duty drawback removal in China after the implementation of China's WTO accession commitments and compare this policy with other reform options for China's post-WTO trading system. This is an interesting case-study because China has had a well functioning duty drawback system for more than two decades, but with the fall in China's post-WTO tariffs and the costs associated with the system time has come to question whether it is worthwhile to keep the system.

The following conclusions emerge from this paper. There is no straightforward answer to the question whether duty drawbacks on exports are worth the hassle. The answer depends on the country's development priorities and economic conditions. An increase in the duty drawback has a positive impact on export competitiveness and employment in the export-oriented industries, but could lead to exports with low domestic value added. ${ }^{12}$ The welfare effects of duty drawback and trade reform are ambiguous. An increase in the drawback is more likely to enhance welfare if the economy is small with negative effective protection on the export processing activities and positive protection on the domestic-oriented activities, high input tariffs and intensity of imported input use in the

\footnotetext{
${ }^{12}$ It is important to point out that changes in domestic value added do not affect the welfare measures presented in this paper. For changes in domestic value added to have welfare consequences the welfare function must reflect features not present in this paper (e.g. love of variety). Furthermore, a strict view of economics is that it does not matter whether exports under duty drawback arrangements have low value added. Still policy makers pay attention to the domestic value added content of their exports since backward and forward linkages affect where goods are produced. In addition, one of the key lessons of the new economic geography literature is that there may be substantial gains from activities that encourage the development of backward and forward linkages (Amiti 2003). Incentives toward shallow processing activities such as duty drawbacks may cause highly protected economies to miss many opportunities for growth. Therefore, this paper reports changes in domestic value added in addition to the welfare estimates.
} 
export-oriented sectors, low initial drawback, and low administrative costs and leakages in the tariff collection system. We find that duty drawback removal after China meets its WTO commitments will deepen domestic supply chains and improve welfare, but will hurt China's economic efficiency, output growth, export competitiveness in key manufacturing industries and real factor incomes. Further liberalization could mitigate the negative effects.

Section 2 introduces a model for the welfare analysis of duty drawback and trade reform. Section 3 presents the empirical multi-region, multi-sector general equilibrium model with duty drawbacks. Section 4 discusses key features of China's duty drawback system and analyzes reform options for China's post WTO trading system. Section 5 concludes.

\section{Welfare analysis of duty drawback and trade reform}

We use a modified Panagariya (1992) type model to which we add domestic tax distortions and completely separated production for export and domestic markets. The separation between domestic and export markets is preferable to the one based on a single sector producing for domestic and export markets since it allows the two sectors to use different input mixes, and the export-oriented activities to use much more import-intensive means of production. ${ }^{13}$ It is also a fairly accurate depiction of the trade regime in countries where duty drawbacks are used as export promotion instruments while protection on the rest of the economy is fairly high. ${ }^{14}$ Unlike Panagariya (1992) we do not restrict the analysis to a

\footnotetext{
${ }^{13}$ Ianchovichina (2004) found that exporting activities in China had become much more import-intensive than other industries because of the incentives created by duty exemptions.

${ }^{14}$ In a deterministic world, an export producer will always take advantage of duty drawbacks or rebates unless the administrative costs are prohibitive.
} 
small open economy. This assumption simplifies the analysis, but may not be appropriate for countries that are large enough to affect world prices of some product groups.

We have an open economy with perfectly competitive markets. There are 3 industries $(D, X$, and $N)$ producing 3 final goods using $F$ factors of production. Industry $D$ specializes in good $D$, which competes with imports and is sold in the domestic market only. Industry $X$ specializes in export good $X$ sold only abroad. Industry $N$ produces a freely traded $\operatorname{good} N$. Final goods $D$ and $X$ use an imported intermediate good $M$, which is not produced at home, while good $N$ does not use the imported good. We assume that the value added $\left(V_{j r}\right)$ is a linear homogenous function, transport costs are negligible, export taxes and taxes on intermediate inputs and factor inputs are zero.

The supply price of good $D\left(p^{D}\right)$ is the world price $p^{D^{W}}$ adjusted for any import tariffs $(t)$, and output taxes $\left(\tau^{D}>0\right)$ or subsidies $\left(\tau^{D}<0\right)$, i.e. $p^{D}=p^{D^{W}}\left[(1+t) /\left(1+\tau^{D}\right)\right]$. The supply price of $\operatorname{good} X\left(p^{X}\right)$ is the world price $p^{X^{W}}$ adjusted for any export taxes $\left(\tau^{X}>0\right)$ or subsidies $\left(\tau^{X}<0\right)$, i.e. $p^{X}=p^{X^{W}} /\left(1+\tau^{X}\right)$. We choose the units of value added in such a way that it takes 1 unit of value added to produce 1 unit of a final product. From these assumptions and the zero-profit condition it follows that the prices of valueadded in sectors $D$ and $X$ are respectively:

$$
\begin{aligned}
& p_{v_{D}}=p^{D^{W}}(1+t) /\left(1+\tau^{D}\right)-\left(1+t^{M}\right) a^{D} p^{M^{W}}, \\
& p_{v_{X}}=p^{X^{W}} /\left(1+\tau^{X}\right)-\left(1+t^{M}(1-\phi)\right) a^{X} p^{M^{W}},
\end{aligned}
$$

where $p^{M^{W}}$ is the world price of the input $\operatorname{good} M, t^{M}$ is the tariff on the input $M, a^{i}$ $(i=X, D)$ is the input-output ratio in sector $i$. If $\phi=1$, the export-oriented sector gets a complete duty drawback of import duties paid on inputs used in the production of exports. 
If $0<\phi<1$, the export-oriented sector gets a partial duty drawback. If $\phi=0$, there is no duty drawback and import taxes are the same for sectors $X$ and $D$.

Under free trade and no domestic distortions, the price of value added in sector $i$ is:

$$
p_{v_{i}}^{*}=p^{i^{W}}-a^{i} p^{M^{W}}, \quad i=X, D
$$

The effective rates of protection (ERPs) in domestic and export-oriented sectors are therefore:

$$
\begin{aligned}
& e^{D} \equiv \frac{p_{v_{D}}-p_{v_{D}}^{*}}{p_{v_{D}}^{*}}=\frac{p^{D}-t^{M} a^{M} p^{M^{W}}-p^{D^{W}}}{p_{v_{D}}^{*}}= \\
& \frac{p^{D^{W}}\left(t-\tau^{D}\right) /\left(1+\tau^{D}\right)-t^{M} a^{M} p^{M^{W}}}{p_{v_{D}}^{*}}, \\
& e^{X} \equiv \frac{p_{v_{X}}-p_{v_{X}}^{*}}{p_{v_{X}}^{*}}=\frac{p^{X}-p^{X^{W}}-t^{M}(1-\phi) a^{X} p^{M^{W}}}{p_{v_{X}}^{*}}= \\
& \frac{-p^{X^{W}} \tau^{X} /\left(1+\tau^{X}\right)-t^{M}(1-\phi) a^{X} p^{M^{W}}}{p_{v_{X}}^{*}} .
\end{aligned}
$$

Under free trade $\left(t=t^{M}=0\right)$ and no domestic distortions $\left(\tau^{D}=\tau^{X}=0\right)$, the price of value added of the import competing, domestic-oriented sector $D$ is $p^{D^{W}}-a^{D} p^{M^{W}}$, while that of the export-oriented sector $X$ is $p^{X^{W}}-a^{X} p^{M^{W}}$. In this case the ERPs on both sectors are 0 . If the tariff on the final good is high enough so that $t \geq\left[t^{M} a^{D} p^{M^{W}}+\left(t^{M} a^{D} p^{M^{W}}+p^{D^{W}}\right) \tau^{D}\right] / p^{D^{W}}$, the ERP of sector $D$ is positive. This is more likely to be the case when tariffs are uniform or escalating $\left(t \geq t^{M}\right)$ and there is an output $\operatorname{tax} \tau^{D} \geq 0 .{ }^{15}$

The ERP of sector $X$ is negative unless the sector gets an export subsidy $\left(\tau^{X} \geq 0\right)$. If there is a complete duty drawback $(\phi=1)$, the ERP of sector $X$ becomes 0 when all other

\footnotetext{
${ }^{15}$ In the case of a subsidy we assume that subsidy rate $\tau$ is less than $100 \%$ so that the power of the subsidy $(1+\tau)$ is positive.
} 
distortions in sector $X$ are zero $\left(\tau^{X}=0\right),{ }^{16}$ negative when $X$ is taxed $\left(\tau^{X}>0\right)$, and positive when $X$ is protected with an export subsidy $\left(\tau^{X}<0\right)$.

The equilibrium in the economy is given by:

$$
R\left(p_{v_{D}}, p_{v_{X}}, 1\right)+T=E\left((1+t) p^{D^{W}}, 1 ; u\right)
$$

where $R\left(p_{v_{D}}, p_{v_{X}}, 1\right)^{17}$ is the revenue function of the economy obtained by maximizing the GDP subject to full employment; $E\left((1+t) p^{D^{W}}, 1 ; u\right)$ is the expenditure function obtained by minimizing spending in order to achieve welfare no worse than $u ;^{18}$ and $T$ is the tax revenue, collected by the government and distributed to consumers:

$$
\begin{aligned}
T & =t p^{D^{W}}\left(E_{1}-R_{1}\right)+t^{M} a^{D} p^{M^{W}} R_{1}+t^{M} a^{X} p^{M^{W}} R_{2}-t^{M} \phi \cdot a^{X} p^{M^{W}} R_{2} \\
& +\tau^{D} p^{D} R_{1}+\tau^{X} p^{X} R_{2} .
\end{aligned}
$$

The first term is the tariff revenue raised from imports of good $D$, the second and third terms specify the tariff revenue raised from imports of intermediate inputs used for the production of goods $D$ and $X$, the fourth term is the expenditure made on the duty drawbacks, the fifth and sixth terms are the revenue (expenditure) associated with output taxes (subsidies) in sectors $D$ and $X$, respectively. ${ }^{19}$

We assume that the economy is distorted in the initial equilibrium $\left(t \neq 0, t^{M} \neq 0, \tau^{D} \neq 0, \tau^{X} \neq 0\right),{ }^{20}$ the domestic-oriented sector $D$ faces positive ERPs $\left(e^{D}>0\right)$, while the export-oriented sector $X$ faces negative ERPs $\left(e^{X} \leq 0\right)$. Ceteris paribus, the ERP

\footnotetext{
${ }^{16}$ In this case, there is still an anti-export bias unless protection to sector $D$ is negative because of an output tax.

${ }^{17}$ The vector of factor endowments has been suppressed for the sake of brevity.

${ }^{18}$ Since good $X$ is not consumed domestically $E$ (.) is a function of prices of goods $D$ and $N$ only.

${ }^{19}$ Assuming that good $D$ is good 1 , while good $X$ is good 2, the supply of good $i$ is given by the first partial of $R$ (.) with respect to the $i$ th argument. The demand for good 1 is given by the first partial of $E$ (.) with respect to the 1st argument. The assumption that all of product $X$ is exported implies that the domestic demand for good $X$ is zero.

${ }^{20} \mathrm{We}$ assume that trade and domestic taxes are exogenous.
} 
of sector $D$ is more likely to be positive, the higher the tariff on final imports, and the output subsidy in sector $\mathrm{D}$, and the lower the intensity of imported input used in sector $D$, and the input tariff. Ceteris paribus, the ERP of sector $X$ is more likely to be negative the higher the export tax on sector $X$, and the lower the initial duty drawback. ${ }^{21}$

We look at the welfare effects of the following three policy scenarios: (2.1) duty drawback reform; (2.2) liberalizing trade in intermediate inputs; and (2.3) liberalizing trade in final and intermediate products. In all three scenarios we discuss separately the following two special cases: (i) the respective policy reform without duty drawback in the initial equilibrium $(\phi=0)$; (ii) the policy reform with complete duty drawback in place in the initial equilibrium $(\phi=1)$. World prices are reduced-form functions of the reform variables, i.e. $p^{D^{W}}\left(\phi, t^{M}, t\right), \quad p^{X^{W}}\left(\phi, t^{M}, t\right)$, and $p^{M^{W}}\left(\phi, t^{M}, t\right)$.

\subsection{Duty drawback reform}

The welfare effect of a change in the duty drawback policy can be assessed by totally differentiating the equilibrium condition (A) and setting $d t=d t^{M}=d \tau^{D}=d \tau^{X}=0$.

$$
\begin{aligned}
\left(E_{u}-t p^{D^{W}} E_{1 u}\right) & \frac{d u}{d \phi}=-\left(E_{1}-R_{1}\right) \frac{\partial p^{D^{W}}}{\partial \phi}-\left(a^{D} R_{1}+a^{X} R_{2}\right) \frac{\partial p^{M^{W}}}{\partial \phi}+R_{2} \frac{\partial p^{X^{W}}}{\partial \phi} \\
& -\left(\mathrm{R}_{12} e^{D} p_{v_{D}}^{*}+R_{22} e^{X} p_{v_{X}}^{*}\right) \frac{\partial p_{v_{X}}}{\partial \phi}-\left(\mathrm{R}_{11} e^{D} p_{v_{D}}^{*}+R_{21} e^{X} p_{v_{X}}^{*}\right) \frac{\partial p_{v_{D}}}{\partial \phi}
\end{aligned}
$$

Unless otherwise noted, we assume that goods exhibit substitutability in production (i.e. $R_{12}<0$ ), demand is downward sloping, while supply is upward sloping (i.e. $E_{11}<0$ and $R_{11}>0, R_{22}>0$ ), and goods are normal so that the term on the left-hand side of (B) is positive. Therefore, the sign of $d u / d t^{M}$ is the same as the sign of the right-hand-side of (B).

\footnotetext{
${ }^{21}$ Notice that under this specification ERPs may be nonzero even when import taxes are zero $\left(t=t^{M}=0\right)$.
} 
The first three terms on the right-hand-side of equation (B) capture the terms of trade effect of duty drawback reform. In general this effect is ambiguous. The sign of the first term depends on whether the country is a net importer or exporter of good $D$ and whether the increase in the drawback reform leads to an increase or decrease in the world price of good $D$. For instance, an increase in the duty drawback may lead to a rise in the world price of good $M$ following an increase in the demand for the input in sector $X$, a drop in the world price of good $X$ following an increase in the supply of good $X$, and a rise in the world price of good $D$ as the domestic sector contracts and imports of good $D$ rise. In this case, the terms of trade effect is likely to be negative.

The last two terms depict the resource allocation effect (or the allocative efficiency effect) of duty drawback reform. In general this effect is ambiguous. It will be positive (negative) if the price of value added in sector $\mathrm{X}$ rises (drops), while the price of value added in sector $\mathrm{D}$ drops (rises). In this case the increase in the drawback leads to an expansion of the export-oriented sector $\mathrm{X}$, which faces negative ERPs $\left(e^{X}<0\right)$, and a contraction of the protected domestic-oriented sector $\mathrm{D}\left(e^{D}>0\right)$. Both changes increase welfare.

In the case when world prices are fixed, the welfare effect of duty drawback reform is determined entirely by the resource allocation effect. ${ }^{22}$

$$
\left(E_{u}-t p^{D^{W}} E_{1 u}\right) \frac{d u}{d \phi}=-a^{X} t^{M} p^{M^{W}}\left(e^{D} p_{v_{D}}^{*} R_{12}+e^{X} p_{v_{X}}^{*} R_{22}\right)
$$

The welfare effect of an increase (decrease) in the duty drawback is unambiguously positive (negative). This is the case because the increase in the drawback results in the rise

\footnotetext{
${ }^{22}$ The case when the country is small and there is one sector producing good $X$ that can be sold both abroad and locally is presented in Panagariya (1992). In this paper, an increase in the duty drawback has an ambiguous consumption effect since consumption of good $X$ declines and that of good $D$ increases. This leads to the conclusion that the effect of an increase in the duty drawback is ambiguous in general.
} 
of the value added in sector $X$ followed by an expansion of the negatively protected exportoriented sector and a contraction of the positively protected domestic-oriented sector. Both changes are welfare enhancing.

The intensity of input use in the export-oriented sector $X$ and the tariff on the imported input are proportionate to the welfare effect of tariff reform. The higher the intensity of imported input use in the export-oriented sector or the tariff on the imported input, the larger the effective rate of protection on sector $X$ and the increase in the price of value added in the export sector, in turn implying a larger welfare change as this distortion is reduced. The extent of the drawback is inversely related to the welfare effect of tariff reform. A higher extent of the drawback $\phi$ implies lower absolute value of the ERP in the export-oriented sector and a lower welfare change of duty drawback reform (see equation B'). This leads us to proposition 1.

Proposition 1. The welfare effect of a small increase (reduction) in the duty drawback is ambiguous in general. If the country is small the welfare effect of a small increase (decrease) in the drawback is unambiguously positive (negative). In this case the higher the intensity of imported input use in the export-oriented sector and the tariff on the imported input, and the lower the initial drawback, the larger the magnitude of the welfare effect.

\subsection{Liberalizing trade in intermediate inputs}

The welfare effect of liberalizing trade in intermediate inputs can be assessed by totally differentiating the equilibrium condition (A) and setting $d t=d \phi=d \tau^{D}=d \tau^{X}=0$. 


$$
\begin{aligned}
\left(E_{u}-t p^{D^{W}} E_{1 u}\right) & \frac{d u}{d t^{M}}=-\left(E_{1}-R_{1}\right) \frac{\partial p^{D^{W}}}{\partial t^{M}}-\left(a^{D} R_{1}+a^{X} R_{2}\right) \frac{\partial p^{M^{W}}}{\partial t^{M}}+R_{2} \frac{\partial p^{X^{W}}}{\partial t^{M}} \\
& +t(t+1) E_{11} p^{D^{W}} \frac{\partial p^{D^{W}}}{\partial t^{M}} \\
& -\left(\mathrm{R}_{12} e^{D} p_{v_{D}}^{*}+R_{22} e^{X} p_{v_{X}}^{*}\right) \frac{\partial p_{v_{X}}}{\partial t^{M}}-\left(\mathrm{R}_{11} e^{D} p_{v_{D}}^{*}+R_{21} e^{X} p_{v_{X}}^{*}\right) \frac{\partial p_{v_{D}}}{\partial t^{M}}
\end{aligned}
$$

The first three terms on the right-hand-side of equation (C) represent the terms-oftrade effect. As discussed earlier in general this effect is ambiguous. A tariff cut on input $M$ is likely to reduce the domestic prices of goods $D$ and $X$, possibly lowering the world prices of goods $D$ and $X$, and increasing the demand and the world price of input $M$. The fall in the world price of good $D$ is welfare enhancing since the country is a net importer of good $D$, while the increase in the world price of input $\mathrm{M}$ and the fall in the world price of good $X$ is welfare reducing since the country is an importer of good $M$ and an exporter of good $X$ and. The net terms-of-trade effect is ambiguous.

The third term captures the allocation effect on the demand side. Its sign depends on whether the price of good $D$ rises or falls following the tariff cuts on good $M$. If the world price of good $D$ drops as a result of the tariff cut on input $M$ (i.e. $\partial p^{D^{W}} / \partial t^{M}>0$ ), there will be an increased consumption of the protected good $D$. This has a positive effect on welfare since in the initial equilibrium there is under-consumption of $D$. Otherwise, the effect is negative.

The last two terms capture the resource allocation effect on the supply side. In general this effect is ambiguous. It is unambiguously positive if the tariff cut increases the prices of value added in the negatively protected export sector $X$ (i.e. $\partial p_{V_{X}} / \partial t^{M}<0$ ), and decreases the price of value added in the protected domestic sector $D$ (i.e. $\partial p_{V_{D}} / \partial t^{M}>0$ ).

In the small country case when world prices are fixed (C) transforms into: 


$$
\begin{aligned}
& \left(E_{u}-t p^{D^{W}} E_{1 u}\right) \frac{d u}{d t^{M}}= \\
& \quad a^{D} p^{M^{W}}\left(R_{11} e^{D} p_{v_{D}}^{*}+R_{21} e^{X} p_{v_{X}}^{*}\right)+(1-\phi) a^{X} p^{M^{X}}\left(R_{12} e^{D} p_{v_{D}}^{*}+R_{22} e^{X} p_{v_{X}}^{*}\right)
\end{aligned}
$$

and the welfare effect is captured entirely by the resource allocation effect of a change in tariffs on intermediate inputs. An unambiguous increase in welfare requires that the decrease in the tariff $t^{M}$ is associated with a contraction of the protected domestic-oriented sector $D$ and an expansion of the negatively protected export-oriented sector $X$. Since in this case this condition is not satisfied, the welfare effect of a decline in tariffs on intermediate imported inputs is ambiguous. However, if there is a complete duty drawback then a tariff cut (increase) on the intermediate imported input is unambiguously welfare reducing (enhancing). This is the case because the tariff cut (increase) leads to an increase (a decrease) in the price of value added in the protected sector D, and an expansion (contraction) of this sector.

Assuming that the economy's only two producing sectors are $D$ and $X$, all of good $N$ consumed is imported, and world prices are fixed at 1 , expression (C) transforms into $\left(C^{\prime}\right):^{23}$

$$
\left(E_{u}-t E_{1 u}\right) \frac{d u}{d t^{M}}=\Omega\left[-\frac{R_{12}}{\left(p_{v_{D}}\right)^{2}} e^{D} p_{v_{D}}^{*}+\frac{R_{21}}{\left(p_{v_{X}}\right)^{2}} e^{X} p_{v_{X}}^{*}\right],
$$

where $\Omega$ is defined as $\Omega=a^{D} p^{X}-(1-\phi) a^{X} p^{D}-a^{X} a^{D} \phi$. The right hand side of (C') will be negative, if and only if $\Omega<0$, or equivalently if $a^{D} /\left((1-\phi) p^{D}+a^{D} \phi\right)<a^{X} / p^{X}$. In this case a reduction in tariffs on intermediate inputs unambiguously enhances welfare.

In order to explain this result let us assume that there is no duty drawback at equilibrium. With a decline in the intermediate tariff, the distortion in production declines

\footnotetext{
${ }^{23}$ Considerable manipulation is required before $(C)$ is transformed into $\left(C^{\prime}\right)$. In deriving $\left(C^{\prime}\right)$ we make use of the property that the supply function $R_{i}($.$) is zero-degree homogenous in prices.$
} 
and welfare rises provided that the costs decline more in the export-oriented sector $X$. This happens if $\Omega<0$, or equivalently if the cost share of the input is higher in the export sector $X$ rather than the domestic-sector $D\left(a^{D} / p^{D}<a^{X} / p^{X}\right)$. Otherwise, the welfare is unambiguously negative.

Let us assume that there is a complete duty drawback at equilibrium. This implies that $\Omega>0$ since the cost share is less than 1 , i.e. $a^{X} / p^{X}<1$. In this case a reduction on tariffs of intermediate products is unambiguously welfare reducing. This result can be explained with the fact that the distortion in production increases since costs decline more in the protected sector than in the export-oriented sector. Costs in the export-oriented sector cannot be further reduced since the sector is already benefiting from the complete duty drawback. The domestic-oriented sector $D$ expands relative to the export-oriented one, leading to an unambiguous decline in welfare.

Noticing that the denominator in $a^{D} /\left((1-\phi) p^{D}+a^{D} \phi\right)$ is a decreasing function of the duty drawback $\phi$, we conclude that the higher the duty drawback the less important are the relative cost shares for the outcome of the tariff reform and the more likely it is that the welfare outcome of a decline in intermediate input tariffs is welfare reducing.

Proposition 2. The welfare effect of liberalizing imports of intermediate inputs is ambiguous. If the country is small with a compete duty drawback at equilibrium, a tariff cut on intermediate inputs is unambiguously welfare reducing. If the country is small and produces only good $X$ and $D$, the welfare effect of such a reform is positive only if $a^{D} /\left((1-\phi) p^{D}+a^{D} \phi\right)<a^{X} / p^{X}$. This is less likely to be true for higher duty drawback and lower intensity of import use in the export-oriented sector. If there is no duty drawback in the initial equilibrium, the welfare effect of a reduction in intermediate input 
tariffs is unambiguously positive when the cost share of the input is higher in the exportoriented sector than in the import-competing sector $\left(a^{D} / p^{D}<a^{X} / p^{X}\right)$.

\subsection{Liberalizing trade in final and intermediate products}

The welfare effect of liberalizing trade in final and intermediate products can be assessed by noticing that in this case:

$$
d u=\frac{\partial u}{\partial t^{M}} d t^{M}+\frac{\partial u}{\partial t} d t,
$$

and obtaining the partial of $u$ with respect to $t^{M}$ and $t$. We calculate the partial with respect to $t^{M}$ by totaling differentiating (A) and setting $d t=d \phi=d \tau^{D}=d \tau^{X}=0$ and the partial with respect to $t$ by totally differentiating (A) and setting $d t^{M}=d \phi=d \tau^{D}=d \tau^{X}=0$. The resulting expression (D) depicts the welfare change as a result of changing both $t$ and $t^{M}$ :

$$
\begin{aligned}
\left(E_{u}-t p^{D^{W}}\right. & \left.E_{1 u}\right) d u=\left[-\left(E_{1}-R_{1}\right) \frac{\partial p^{D^{W}}}{\partial t^{M}}-\left(a^{D} R_{1}+a^{X} R_{2}\right) \frac{\partial p^{M^{W}}}{\partial t^{M}}+R_{2} \frac{\partial p^{X^{W}}}{\partial t^{M}}\right. \\
& +t(t+1) E_{11} p^{D^{W}} \frac{\partial p^{D^{W}}}{\partial t^{M}} \\
& \left.-\left(\mathrm{R}_{12} e^{D} p_{v_{D}}^{*}+R_{22} e^{X} p_{v_{X}}^{*}\right) \frac{\partial p_{v_{X}}}{\partial t^{M}}-\left(\mathrm{R}_{11} e^{D} p_{v_{D}}^{*}+R_{21} e^{X} p_{v_{X}}^{*}\right) \frac{\partial p_{v_{D}}}{\partial t^{M}}\right] d t^{M} \\
& +\left[-\left(E_{1}-R_{1}\right) \frac{\partial p^{D^{W}}}{\partial t}-\left(a^{D} R_{1}+a^{X} R_{2}\right) \frac{\partial p^{M^{W}}}{\partial t}+R_{2} \frac{\partial p^{X}}{\partial t}\right. \\
& +t E_{11} p^{D^{W}}\left(p^{D^{W}}+(1+t) \frac{\partial p^{D^{W}}}{\partial t}\right) \\
& \left.-\left(\mathrm{R}_{12} e^{D} p_{v_{D}}^{*}+R_{22} e^{X} p_{v_{X}}^{*}\right) \frac{\partial p_{v_{X}}}{\partial t}-\left(\mathrm{R}_{11} e^{D} p_{v_{D}}^{*}+R_{21} e^{X} p_{v_{X}}^{*}\right) \frac{\partial p_{v_{D}}}{\partial t}\right] d t
\end{aligned}
$$

The first term in square brackets displays the factors determining the welfare effect of a change in tariffs on intermediate inputs. As discussed in section 2.2 this effect is ambiguous in general. The second term in square brackets presents the factors determining the welfare effect of a change in tariffs on good $D$. 
The first three terms in the second square brackets measure the terms of trade effect of the tariff change on good $D$. In general this effect is ambiguous. The sign of the first term depends on whether the country is a net importer or exporter of good $D$ and whether the tariff cut on good $D$ leads to an increase or decrease in the world price of good $D$. The tariff cut encourages imports of $D$, and leads to a contraction of sector $D$ and an expansion of sector $X$. This in turn may lead to an increase in the world price of good $D$, and a decline in the world price of good $X$. If there is no change in the world input price, the terms of trade effect of trade liberalization is expected to be negative.

The fourth term in the second square brackets captures the allocation effect on the demand side. A tariff cut has a positive effect on welfare since it increases the consumption of good $D$ by reducing its consumption price and there is under-consumption of good $D$ in the initial equilibrium. If the world price of good $D$ increases as a result of the increased imports of $D$, the consumption price of good $D$ may rise leading to a decline in the consumption of good D. This will be welfare reducing. The net effect is ambiguous.

The last two terms in the second square brackets depict the resource allocation effect of a tariff cut. It is unambiguously positive if the tariff cut increases the price of value added in the negatively protected export sector $X$, and decreases the price of value added in the protected domestic sector $D$.

In the small country case, equation (D) transforms into (D'):

$$
\begin{gathered}
\left(E_{u}-t p^{D^{W}} E_{1 u}\right) d u=\left[a^{D} p^{M^{W}}\left(R_{11} e^{D} p_{v_{D}}^{*}+R_{21} e^{X} p_{v_{X}}^{*}\right)\right. \\
+(1-\phi) a^{X} p^{M^{X}}\left(R_{12} e^{D} p_{v_{D}}^{*}+R_{22} e^{X} p_{v_{X}}^{*}\right] d t^{M} \\
+\left[E_{11} \mathrm{t}\left(\mathrm{p}^{\mathrm{D}^{\mathrm{w}}}\right)^{2}-\left(\frac{\mathrm{p}^{\mathrm{D}}}{1+\tau^{D}}\right)\left(R_{11} e^{D} p_{v_{D}}^{*}+R_{21} e^{X} p_{v_{X}}^{*}\right)\right] d t
\end{gathered}
$$

The term in the second square brackets is the welfare effect of a tariff cut on good $D$. It is unambiguously welfare improving. The tariff cut means that the protected sector $D$ 
contracts relative to sector $X$, and the consumption of good $D$ increases as its price falls down. Both changes are welfare improving. A comparison of expressions (D') and (C') suggests that in a small economy liberalizing both final and intermediate input markets is more likely to be welfare enhancing than liberalizing intermediate input markets only.

The welfare effect of liberalizing both intermediate and final goods is unambiguously positive if the country produces only two goods and in the initial equilibrium $a^{D} /\left((1-\phi) p^{D}+a^{D} \phi\right)<a^{X} / p^{X}$. The latter is more likely to be true for lower duty drawback and higher intensity of import use in the export oriented sector. ${ }^{24}$

Proposition 3. The welfare effect of liberalizing both intermediate and final goods is ambiguous. In a small economy liberalizing both final and intermediate input markets is more likely to be welfare enhancing than liberalizing intermediate input markets only. In such an economy producing only goods $D$ and $X$ the welfare effect is unambiguously positive if $a^{D} /\left((1-\phi) p^{D}+a^{D} \phi\right)<a^{X} / p^{X}$ in the initial equilibrium. This is more likely to be true for lower duty drawback and higher intensity of import use in the export oriented sector in equilibrium.

An introduction (removal) of a duty drawback may lead to additional government expenditures (savings) because the administration of a nationwide duty drawback system can be costly and the duty drawback system can be misused leading to leakages in the tariff collection system. These savings (costs) also need to be taken into account when estimating the welfare effect of a duty drawback reform. The lower these costs (savings) the more likely it is that the welfare effect of introducing (removing) a duty drawback will be positive (negative).

\footnotetext{
${ }^{24}$ See section 2.2 for an explanation.
} 
The model in this section is useful for building intuition about the expected welfare outcomes under different policy scenarios. However, it is impossible to determine the direction and magnitude of welfare change without an empirical model. Furthermore, as we show in the case of China the policy concerns go beyond aggregate welfare and are about export competitiveness, sector employment and output, trade and investment flows, domestic value-added, and real factor returns. The applied multi-region, multi-sector model presented next can be used to estimate these effects.

\section{The empirical model}

The empirical model estimates the impact of duty drawback and trade reform on sector employment, exports, imports and output; prices, factor returns; tax revenue and household welfare. We relax a number of the assumptions in section 2 . We increase the number of sectors to capture changes in sector employment, output, and trade. We increase the number of regions to keep track of changes in bilateral trade balances. We no longer assume that producers use only imported intermediate and factor inputs. Instead producers use also domestic intermediate inputs that are substitutes for the imported intermediate inputs. This allows us to capture the effect of duty drawback and trade reform on domestic value added. We assume that trade and output/export taxes are not the only distortions in the economy, but that there are also factor input taxes, consumption taxes, taxes on domestic and imported intermediate inputs, and others. We no longer assume that the value added is a linear homogenous function and transport costs are zero.

As before production for export and domestic markets is completely separated. The choice to fully separate domestic and export production simplifies considerably the representation of duty drawbacks in a large empirical multi-region, multi-sector model. It 
allows the domestic and export-oriented production activities to use different input mixes, ${ }^{25}$ and is an accurate depiction of the dual market structure in China with partially segmented domestic and export markets.

The empirical model represents a world with $R$ economies in which there are $G$ perfectly competitive industries - each using a constant-returns-to-scale technology, $F$ types of production factors, $G$ types of domestic and imported intermediates. The $G$ industries produce $G$ types of goods. ${ }^{26}$ Each industry has a sector $D$ producing only for the domestic market, and a sector $X$ producing for export only.

The production functions are Leontief so efficiency implies that:

$$
\Omega_{j r}=V_{j r}^{\Omega}=I_{i j r}^{\Omega} / a_{i j r}^{\Omega},
$$

where $i, j \in\{1, \ldots, G\}, r \in\{1, \ldots, R\}$, superscript $\Omega \in\{D, X\}$ indicates the type of the sector, $V_{j r}^{\Omega}$ is the value-added of sector $\Omega$ in industry $j$ of region $r, I_{i j r}^{\Omega}$ is the intermediate input demand for input $i$ in industry $j$ of region $r$, and $a_{i j r}^{\Omega}$ is the fixed intermediate input-output coefficient for good $i$ in sector $\Omega$ of industry $j$ in region $r$.

Producers minimize unit factor costs given the vector of factor prices $p_{f r}^{F}$ and relevant taxes $t_{f r}^{F}$, and a CES function that relates the level of output to the factor inputs. Linear homogeneity of the production function implies that factor demands of sector $\Omega$ in industry $j$ of region $r\left(F_{f j r}^{\Omega}\right)$ can be written as:

$$
F_{f j r}^{\Omega}=V_{j r}^{\Omega} a_{f j r}^{F \Omega}\left(p_{f r}^{F}, t_{f r}^{F}\right)
$$

where superscript $F$ stands for factor use, $f \in\{1, \ldots, F\}$.

\footnotetext{
${ }^{25}$ Duty drawbacks lower the cost of imported intermediates encouraging their use. This implies that the intensity of imported intermediate use by the export sector is typically higher than the intensity of imported intermediate use by the sector producing for the local market.

${ }^{26}$ There is a one-to-one correspondence between goods and industries.
} 
Primary factors are fully employed. Their supply is exogenous and equals demand in equilibrium:

$$
F_{f r}=\sum_{\Omega} \sum_{j} F_{f j r}^{\Omega}
$$

The domestic and foreign intermediate inputs are imperfect substitutes in a constant-elasticity-of-substitution (CES) composite function (Armington 1969). ${ }^{27}$ Imports of good $i$ in region $r$ for the production of goods sold domestically and for exports are CES composites of imports from various sources $s, M_{i s r}^{\Omega} \cdot{ }^{28}$ Product differentiation among imports by region of origin allows for two-way trade in each product category, depending on the ease of substitution between products from different sources.

In equilibrium, output of good $i$ from the domestic-oriented sector in an industry $\left(D_{i r}\right)$ meets demand for domestic intermediate products, and final demand for good $i$ in region $r$ :

$$
D_{i r}=\sum_{\Omega} \sum_{j}\left(I_{i j r}^{D \Omega}\right)+C_{i r}^{D}
$$

Output of good $i$ from the export-oriented sector in an industry in region $r$ meets import demand of all trading partners:

$$
X_{i r}=\sum_{\Omega} \sum_{s}\left(M_{\text {irs }}^{\Omega}\right)
$$

Competitive producers in both the export-oriented and domestic-oriented sectors earn zero profit in equilibrium:

$$
p_{i r}^{\Omega}=\sum_{f} a_{f i r}^{F \Omega} p_{f r}^{F}\left(1+t_{f i r}^{F}\right)+\sum_{j} a_{j i r}^{\Omega} p_{j i r}^{I \Omega}\left(p_{j r}^{D}, p_{j r}^{M \Omega}\right)\left(1+t_{j i r}^{I \Omega}\right),
$$

\footnotetext{
${ }^{27}$ This is a standard assumption in this type of applied multi-region CGE models.

${ }^{28}$ Subscript $s$ stands for 'source' region, while subscript $r$ stands for 'destination' region.
} 
where $p_{j r}^{\Omega}$ is the supply price to market $\Omega \in\{D, X\} ; p_{j i r}^{I \Omega}$ - the composite demand price of good $j$ for intermediate use by sector $\Omega$ of industry $i$ in region $r$ is a function of $p_{j r}^{D}-$ the domestic supply price of good $j$ in region $r$, and $p_{j r}^{M \Omega}$ - the import price of good $j$ used for final consumption or as intermediate input by sector $\Omega$ in region $r$; $t_{j i r}^{I \Omega}$ is the tax on intermediate inputs.

In equilibrium, the domestic cif price equals the $f o b$ price gross of export tax, the applicable tariff, and transport costs:

$$
\begin{aligned}
& p_{i r}^{M D}=\sum_{s} a_{i s r}^{M D}\left[p_{i s}^{X}\left(1+t_{i s r}^{X}\right)\right]\left(1+t_{i s r}^{M}\right)\left(1+\tau_{i s r}\right), \\
& p_{i r}^{M X}=\sum_{s} a_{i s r}^{M X}\left[p_{i s}^{X}\left(1+t_{i s r}^{X}\right)\right]\left(1+(1-\phi) t_{i s r}^{M}\right)\left(1+\tau_{i s r}\right),
\end{aligned}
$$

where $t_{i s r}^{M}$ is the import tax on good $i$ from region $s$ to region $r ; t_{i s r}^{X}$ is the export tax on good $i$ from region $s$ to region $r ; \tau_{i s r}$ is the transportation cost of good $i$ from region $s$ to region $r$; and $\phi$ is the parameter determining the extent of the duty drawback.

The model's equations (1) through (8) show that duty drawbacks improve the exporters' competitiveness as their costs either do not reflect import duties or reflect reduced import taxes due to partial duty rebates. Duty drawbacks provide incentives for increased production and employment in the export-oriented sectors and for increased use of imported rather than domestic intermediate inputs thereby creating conditions for shallow domestic supply chains.

In this model we assume that tariffs are exogenous. In general, this assumption can be relaxed by endogenizing tariffs, assuming that the government values welfare as well as lobbying contributions, and calibrating the share of population politically organized as 
capitalist in each sector. ${ }^{29}$ Since it is unclear to what extent China values lobbying from business interests when setting its tariffs, ${ }^{30}$ we keep tariffs exogenous, but vary them to see the impact of changes in tariffs for a given duty drawback policy.

One of the industries produces a non-tradable investment good using both domestic and imported capital goods. This investment good can be installed either in a domestic or an export-oriented sector. Since capital goods brought into China for export processing by foreign-invested enterprises have been exempt from import duties during most of the 1990s, we assume that the imported investment goods installed in the export-oriented sectors of China are duty exempt.

In the background we assume that in each economy there is a single representative consumer, maximizing a constant-difference-elasticity (CDE) demand system. ${ }^{31}$ The representative consumers and the government receive income from payments of primary factor services and tax revenue net of the costs of any duty drawback scheme and subsidy programs, respectively, and save a fixed share of their income. Public consumption is governed by a Cobb-Douglas utility function. As in the case of intermediate inputs, both private and government final demands are a CES composite of domestic and imported products. The consumer price level is the numeraire, and aggregate investment is such that the trade balance is a fixed share of income. ${ }^{32}$

\footnotetext{
${ }^{29}$ This is the method proposed by Cadot et al. (2004).

${ }^{30}$ The discussion in section 4 suggests that China's trade policies aimed at correcting the anti-export bias, increasing employment and incomes, diversifying the production base, increasing foreign exchange proceeds and investment.

${ }^{31}$ The CDE implicit expenditure function, proposed by Hanoch (1975), is less restrictive than other functional forms in that the elasticities of substitution between pairs of commodities can differ and income elasticities are not restricted to equal one.

${ }^{32}$ The assumption of fixed trade balance as a share of GDP is required when evaluating welfare impacts using a static global empirical model.
} 


\section{Are duty drawbacks worth the hassle? The case of China}

This section analyzes reform options for China's post-WTO trading system. We start with a description of China's duty drawback system, followed by a specification of the data and simulation design, and finally a discussion of the results.

\subsection{China's duty drawback system}

Duty drawbacks in the form of tariff exemptions have been a central feature of China's export processing system. Introduced in 1979 in order to improve the country's competitiveness by reducing the anti-export bias in the country's economic climate, ${ }^{33}$ initially the system provided various incentives for both the processing of raw materials for export and the assembly of imported parts and components to produce finished goods for export (known as processing and assembling or processing with supplied materials). In 1986-87 these incentives were expanded to allow for duty-free imports of all raw materials and intermediate inputs used in the production of exports, ${ }^{34}$ and later to imported capital

\footnotetext{
${ }^{33}$ In the pre-reform era exchange rates, tariffs and relative prices had little influence on the magnitude and commodity composition of China's foreign trade. Firms producing for export sold their products to foreign trade companies at officially established domestic prices, fixed in domestic currency. Export producers did not get the foreign exchange income from the sale of their products on international markets and thus had little incentive to expand production of goods for which foreign demand was strong (Lardy, 2002). The prices of imports also distorted the distribution of resources in the economy. Approximately 80 percent of imports were sold in China at prices similar to those of comparable products, quoted in domestic currency, and adjusted up or down to reflect quality differences. This price setting process isolated domestic firms from the influence of relative domestic and international price changes on the import pattern and from exchange rate changes. For imports without domestic equivalents, which accounted for 20 percent of all imports, domestic prices were based on the cost of imports converted to domestic currency at the official exchange rate. Since this exchange rate was overvalued, the imports were in effect subsidized. The consequences of these policies were (1) lack of foreign exchange for imports due to low exports; (2) low growth in trade volume; (3) distorted commodity composition of foreign trade, particularly on the export side, which did not correspond to China's comparative advantage in the production of labor intensive goods.

${ }^{34}$ Companies involved in export processing benefited from other tax concessions such as value-added tax (VAT) exemptions on imported goods. Benefits differed depending on the location of the company and were greatest for companies located, for instance, in bonded areas and EPZs. Benefits in these areas included not only tariff and other tax exemptions, but also speedy customs processing, good infrastructure and others. Since these issues are not the primary focus of the paper, they are omitted from further discussion.
} 
goods supplied by foreign firms to Chinese companies when the equipment was needed to fulfill processing contracts. ${ }^{35}$

On the eve of accession (2000), export processing trade accounted for 41 percent of imports and 55 percent of exports in China. The remaining 45 percent of exports, called ordinary exports, were produced mainly with domestic inputs and only a small portion of duty-paid imported materials. ${ }^{36}$ According to the Customs authorities, in 2000, 60 percent of imports entered China duty-free, out of which 41 percentage points were imports used for export processing, 13 percentage points were capital goods, and 6 percentage points were goods that fell in special categories. ${ }^{37}$

\subsubsection{Benefits associated with duty drawbacks in China}

Duty drawbacks in China reduced the anti-export bias of the old planned economic system and improved the competitiveness and efficiency of the economy by allowing export producers to import at international prices. In the absence of duty exemption schemes, exporters in China would have faced negative effective rates of protection (Figure 1 in Ianchovichina 2004). Duty drawbacks reduce the negative effective rates of protection (ERPs) for export competing firms, allowing many export producers to operate at world prices and compete more effectively in world markets. Duty drawbacks reduce the dispersion in ERPs (Table 2), and therefore increase economic efficiency (Bach and Martin, 2001).

\footnotetext{
${ }^{35}$ China's State Council decided to eliminate these exemptions as of April 1, 1996. However, this deadline was not strictly enforced and eventually the exemption program was formally re-established (Lardy, 2002). ${ }^{36}$ According to version 4 GTAP database (McDougall et al., 1998), in 1995 China's firms exported on average 10 percent of their output and 14 percent of Chinese imports were for final consumption. According to China's Customs 40 percent of imports were ordinary imports that were not duty exempt. Thus, approximately 26 percent were ordinary imports used as intermediates, implying that approximately less than 3 percent of imports were used for the production of ordinary exports.

${ }^{37}$ These categories included materials used by research institutions and products used by the disabled when these products were unavailable in China.
} 
Duty drawbacks boosted trade growth in China as they lowered the cost of imported inputs thus increasing export competitiveness. Right after their introduction in 1979, processing trade comprised only 5 percent of Chinese trade flows. By 1988 processing trade more than doubled. Between 1988 and 1991 processed exports produced with inputs purchased from abroad almost tripled, increasing from US\$140 million in 1988 to US\$324 million in 1991 (Table 1), while total exports rose by 50 percent over the same period (World Bank, 1994). In 2000, processing trade accounted for 50 percent of total trade, with export processing accounting for 55 percent of total exports. ${ }^{38}$

Duty drawbacks facilitated China's integration into the world production sharing system, which in turn speeded up the diversification of Chinese manufactured exports (Lemoine and Ünal-Kesenci, 2004). Textile and garment producers pioneered export processing trade (Naughton, 2000), and despite the restrictive effect of the textile and apparel quotas in North America and Western Europe, made China the largest exporter of textiles and clothing in the world accounting for 8.8 percent of world textile exports and 16.2 percent of world clothing exports in 1999. China later emerged as an important exporter of toys, sports goods, and more recently electronics, telecommunications and electrical equipment (Lardy, 2002).

The boom in the export-oriented sector created millions of jobs. ${ }^{39}$ It speeded up the transition of the Chinese economy from an agrarian to an industrial society and shaped China's industrial composition to reflect the country's comparative advantage in products that are intensive in its most abundant resource - low skilled labor.

\footnotetext{
${ }^{38}$ These statistics are based on data for 2000 from Customs General Administration, People's Republic of China.

${ }^{39}$ Source: Ministry of Foreign Trade and Economic Cooperation (MOFTEC), China.
} 
Foreign direct investment (FDI) was also affected positively as foreign-invested enterprises relocated production to China in order to take advantage of duty drawbacks and other benefits of the export processing regime. Zhang and Song (2000) provide evidence that inward FDI is the most important factor determining export performance in China and isolate duty drawbacks as the most fundamental factor explaining the expanding exports by foreign-invested enterprises. Estimates suggest that approximately 27 percent of actual FDI has gone to the export processing sectors. ${ }^{40}$

\subsubsection{Problems with China's duty drawback system}

Duty drawbacks are commonly associated with leakages in the tariff collection system, fraud related to misuses of the duty drawback system, high administrative costs, trade imbalances, and exports with low domestic value-added. Next we discuss whether these issues have been pronounced in China.

Tariff collection rates in China have stayed low for more than two decades (19812000) (Table 1). At its peak the tariff collection rate was slightly above 16 percent, at its lowest it was close to 2 percent. Throughout the period the average, statutory tariff rate was much higher than the tariff collection rate (Table 1). The large discrepancy between statutory and actual tariff collection rates could be attributed mainly to the rising share of duty-free imports in total imports (Table 1), and less to fraudulent uses of duty drawbacks. The share of imports subject to any import duty in China has declined with the growth in export processing activities. In 2000, when only 40 percent of imports were subject to any tariff, the effective average tariff rate was 6.8 percent, just 2.8 percentage points higher

\footnotetext{
${ }^{40}$ This estimate is based on the following estimates by the Beijing office of BNP Paribus Peregrine Securities Limited for 2000: 54 percent of committed FDI when to the manufacturing sector, 50 percent of FDI in manufactures was for export processing, the delivery ratio was 52 percent (i.e. the actual FDI was 52 percent of the committed FDI).
} 
than the actual tariff collection rate of 4 percent. $^{41}$ These numbers suggest that in 2000 the leakage in the tariff collection system associated with export-related fraud was not larger than US\$63 million or 2.8 percent of total imports. Since by 2007 the simple average tariff will fall to $9.8 \%$, the leakage in the tariff collection system is expected to be negligible.

The costs of administering China's duty drawback system have been modest. According to China's General Administration of Custom, there were 40,000 Customs employees in 2001. Approximately 3,000 Customs employees were involved in visiting production facilities, registering and processing export processing contracts. In addition, there were officials who investigated various violations of the export processing trade rules. These numbers suggest that around 10 percent of the total Customs' labor force monitored processing trade. Assuming that customs officers received the average government wage, ${ }^{42}$ the cost of duty exemption administration in 2001 is estimated at 48,568,000 Yuan or US\$5.9 million.

Despite the low administrative costs and leakages in the tariff collection system associated with export processing trade, China's duty drawback system is not without problems. The export processing system has led to a highly concentrated export market for Chinese products. China's imports for processing trade come mainly from other parts of East Asia, such as Hong Kong, Taiwan, Korea, and Japan, while its exports go predominantly to the United States, the European Union, and Japan. ${ }^{43}$ Among all its trading partners the largest US trade deficit is with China (\$US113 billion in 2002). ${ }^{44}$ It accounts for approximately 20 percent of the total US trade deficit. Naughton (2000)

\footnotetext{
${ }^{41}$ Tariff collection rates were lower than 3 percent between 1994 and 1998. In 1999 they jumped to slightly more than 4 percent as a result of the government's anti-smuggling efforts and the policy of encouraging domestic demand through government spending.

${ }^{42}$ According to China Statistical Yearbook (2002) the average government wage in 2001 was 12,142 Yuan.

${ }^{43}$ Lardy (2002) reports China's trade surplus with the United States to be around US\$69 billion.

${ }^{44}$ Source: WITS/COMTRADE.
} 
estimates that the huge U.S. deficit with China under export processing trade overwhelms the tiny U.S. surplus with China under ordinary trade. With WTO accession these trade imbalances might deepen, leading to an escalation in trade-related tensions with the United States, and increasing the chances of anti-dumping cases filed against China in the coming years. $^{45}$

Perhaps the most serious concern is that the duty exemption system has created incentives for growth in exports with little domestic value-added and low profit margins. Protection of the domestic market raises the prices of non-tradeables and tradeables with high domestic content. This discourages the use of domestic raw materials and products, and implies that the domestic sector is not competitive by international standards.

Furthermore, companies involved in export processing are typically part of production networks (Borrus et al., 2000). They import intermediates from parent firms in Asian countries or buy from their affiliates on the Mainland (Lemoine and Ünal-Kesenci, 2004), while high value added functions such as research, design, and marketing are carried out in developed countries. ${ }^{46}$

The share of in-China value-added in 1992 was only 20 percent or less of the value of processed exports (Naughton, 2000). This is not surprising since duty and other tax drawbacks, local content requirements and foreign balancing rules ${ }^{47}$ discouraged domestic

\footnotetext{
${ }^{45}$ U.S. International Trade Commission's (USITC) report on antidumping and countervailing duty orders in place as of February 4, 2004 suggests that antidumping orders against China have increased after 2002. There were 6 anti-dumping orders filed in 2003. With the exception of 1991, when USITC filed 7 anti-dumping cases against China, this is the largest number of such cases against China filed by USITC in any single year since 1983, (http://www.usitc.gov/).

${ }^{46}$ The case of the hard disk drives (HDD) produced by Seagate's Wuxi facility is a good example. The valueadded within China, including wages, overhead, and a portion of transport costs is estimated to be at most 10 percent of the total value of the HDD. Most of the value of the HDD comes from research, design, marketing, management of supply chains, and other processes, which are primarily done in the United States (Gourevitch et al. 1997).

${ }^{47}$ Foreign balancing rules required companies selling domestically to source 70 to 80 percent of intermediates from domestic producers and to finance imports by selling exports.
} 
companies selling locally from using imported intermediates. Complex administrative rules discouraged export processing companies from selling locally. ${ }^{48}$

The share of domestic value-added has risen since then to more than $30 \%$ in 2000 partly because the share of profit margins and/or wage costs may have increased more rapidly than the costs of imported inputs. But also because of the growing integration of the production process in China, where the value-add chain now includes packaging and marketing, which were previously carried out in Hong Kong, and the shift in processing activities toward machinery, which has higher local content than textiles and electronics.

However, Maruya (2000) provides evidence that the increased local content is due to a rise in transactions among foreign affiliates located in China and that procurement from Chinese companies has remained low. Some of the reasons explaining the weak linkages between the export and domestic-oriented sectors are the higher quality of imported intermediates, the tighter delivery schedules of foreign suppliers, the difficult access of foreign firms to local primary products (agricultural goods and raw materials). Dual market structure and the constraints to private sector growth ${ }^{49}$ may have slowed down the technological upgrading of domestic companies (Lemoine and Ünal-Kesenci, 2004).

\subsection{Reform options for China's post-WTO trading system}

China's compliance with its WTO commitments will unify to a large degree export and domestic markets. By 2007 weighted average statutory tariffs on manufactures will fall to $6.9 \%$ (Table 2). Competition in the domestic market will intensify and economic efficiency

\footnotetext{
48 Failure to obtain in advance a license to sell domestically was considered smuggling. Granting the permission required the involvement of a number of government agencies. Naughton (2000) compared China's trading system to that of Thailand and assessed the degree of dualism in China to be greater than that in Thailand because of the greater importance of government bureaucratic interference in China.

${ }^{49}$ Huang (2003) argues that legal discrimination and limited access to bank credit constrained the growth of local firms.
} 
will increase with the fall in protection. The dualism of the market structure will be further reduced with the abolition of the complex trading rights system, ${ }^{50}$ local content requirements, and foreign balancing rules.

China's WTO accession commitments do not require the duty drawback removal, ${ }^{51}$ yet given the fall in statutory tariffs and the negative aspects associated with the drawback system, it becomes important to assess ways of unifying the country's tariff structure. One way to accomplish this will be to remove duty drawbacks after 2007. An alternative way will be to remove tariffs on manufactured imports thus making duty drawbacks irrelevant. Yet another alternative is to abolish duty drawbacks and halve tariffs on manufactures.

We use the empirical multi-region, multi-sector general equilibrium model in section 3 to provide answers to some of these questions. The results however should be interpreted with caution. They are not predictions but are estimates reflecting the model's assumptions and the key forces driving the outcomes.

\subsubsection{Data and simulation design}

The starting point for the numerical simulations is the modified GTAP version 5 database in Ianchovichina and Martin (2004). This database is aggregated to 20 regions, 25 sectors and 5 factor inputs and is changed to reflect the presence of duty drawbacks. ${ }^{52}$ The database also reflects growth in the world economy to $2007^{53}$ and the implementation of

\footnotetext{
${ }^{50}$ China has agreed to terminate limitations on trading rights upon WTO accession, and in the case of designated trading over a 5 year period.

${ }^{51}$ WTO explicitly allows duty drawbacks/exemptions for use in the production of export up to the value of the liable duty.

${ }^{52}$ Ianchovichina (2004) discusses in detail the implementation of the empirical model in GEMPACK (Harrison and Pearson, 1996) and the changes to the GTAP data necessary to incorporate duty drawbacks.

${ }^{53}$ The growth projections are based on World Bank projections for aggregate real GDP and factor input growth in each region in the model and a residually determined total factor productivity growth rate to ensure consistency between the two. These projection rates are shown in Table 4 of Ianchovichina and Martin
} 
China's WTO accession commitments. ${ }^{54}$ This is important since all post-WTO reform options are evaluated on the background of the implemented WTO commitments. For comparison purposes we use the same set of elasticities and tax distortions as in Ianchovichina and Martin (2004) (Table 4A). These originally come from GTAP version 5 database (Dimaranan and McDougall 2002).

The macro closure for the empirical model is one of full employment, perfect mobility of skilled and unskilled workers between nonagricultural sectors, and perfect mobility of unskilled workers within agriculture. However, there are barriers to labor mobility between rural and urban employment (see Ianchovichina and Martin, 2004). To capture the effects of these barriers to mobility, the model allows for both imperfect transformation between unskilled workers in agricultural and unskilled nonagricultural employment, and an implicit tax on nonagricultural employment. The imperfect transformation reflects the substantial differences in farm and nonfarm unskilled workers' characteristics, and the ability to transform at a cost farm into nonfarm workers through training, experience, and the creation of nonfarm jobs in rural areas. ${ }^{55}$ The tax is designed to reflect the pure policy-induced barriers between rural and urban workers, such as the cost of a residence permit and the inability to sell farm land. ${ }^{56}$

(2004), available also as a World Bank Policy Research Working Paper at http://econ.worldbank.org/files/26864_wps3053.pdf.

${ }^{54}$ China's WTO accession commitments include reduction in protection to post-accession (2007) tariff levels, liberalization of the services sectors, restructuring of the automobile sector, removal of quotas on China's clothing and textile exports, and China's agricultural export subsidies.

${ }^{55}$ We set the elasticity of transformation at 1.32. This is the estimate by Sicular and Zhao (2002) used in Ianchovichina and Martin (2004).

${ }^{56}$ The tax reflecting pure policy-induced barriers between rural and urban wages is set at 34 percent. This is the estimate by Shi (2001) used in Ianchovichina and Martin (2004). Even though the government recently removed the requirement for a residence permit in urban areas, in practice migrant workers in urban areas still need to incur the costs of health care and schooling for children in urban areas. 


\subsubsection{Impact of duty drawback removal in China}

Duty drawback removal after implementing China's WTO accession commitments has a small positive effect on welfare in China (Table 3) ${ }^{57}$ Aggregate welfare increases by US\$3.8 billion per year due to an improvement in China's terms of trade. The decline in export supply puts an upward pressure on China's export prices and the world prices of China's biggest export items (e.g. apparel and textiles, and light manufactures) and a downward pressure on China's import prices (Table 4B).

Efficiency losses diminish the positive terms-of-trade effect (Table 3). The exportoriented sectors contract because they no longer benefit from the duty drawback. The domestic sectors' expand absorbing the workers who leave their export processing jobs. This is welfare reducing since even with duty drawbacks the export-oriented sectors have negative ERPs, reflecting the sectors' tax burden and protection on domestic intermediate inputs, while the domestic sectors have positive ERPs (Table 2). A small welfare loss is associated with the contraction of the export processing sectors as they are primarily manufacturing sectors, which in China face higher employment-related taxes than other sectors (e.g. agriculture) ${ }^{58}$

The direction of the allocation effect is consistent with the predictions of the model in section 2. There we show that the resource allocation effect of duty drawback removal is unambiguously negative when the expanding domestic sector's ERP is positive and the contracting export-oriented sector's ERP is negative.

The welfare gain from the duty drawback removal may be smaller than US\$3.8 billion. First, Bach and Martin (2001) show that the increased dispersion in ERPs

\footnotetext{
${ }^{57}$ Remembering the notation of sections 2 and 3, we change $\phi$ from 1 to 0 implying that the export-oriented sectors must pay post-WTO statutory tariffs (Table 2).

${ }^{58}$ Employment taxes in non-farm industries of $34 \%$ reflect the cost of a residence permit and the inability to sell farm land.
} 
augments economic efficiency losses. Second, the empirical model with Armington structure may overstate the terms of trade effect (Brown, 1987). ${ }^{59}$ Although China is a large producer and exporter of some manufactured products, it is unlikely that it will have market power to lift its export prices to the extent represented in the model. ${ }^{60}$ Intense competition in world markets for China's most important exports - apparel, toys and other light manufactures implies small price changes and quick supply responses.

In order to illustrate the impact of increased competition on the terms of trade we double the elasticities of substitution between domestic and imported goods, and between imports from different regions. ${ }^{61}$ As a result the welfare gain drops to US\$2.6 billion, mainly because of a much smaller export price effect (US\$3.8 billion), and a larger negative resource allocation effect (US\$2.3 billion). The resource allocation effect is large since the higher substitutability between products suggests larger export and import quantity changes. In the case of perfect substitution between domestic and imported goods, and between imports from different regions we expect to see the terms of trade gains further eroded ${ }^{62}$ and the welfare gain reduced to zero.

While duty drawbacks removal will not affect negatively aggregate welfare, it will hurt China's competitiveness and exports (Table 4A). The volume of total exports decline by $6 \%$ and sectors in which export processing is important contract with the higher input

\footnotetext{
${ }^{59}$ While Brown and others make the point that in Armington-type models with national product differentiation the terms of trade effects tend to dominate the welfare results, Francois and Shiells (1994) argue in favor of the Armington assumption in empirical trade models. They show that the Armington and monopolistic competition specifications are identical if the number of domestic and foreign product varieties is unchanged in equilibrium, allowing for free entry and exit.

${ }^{60}$ See the export price component of the terms of trade effect (US\$4.1 billion) in Table 4B.

${ }^{61}$ This implies reduced degree of product differentiation between imports and domestic goods, and imports by country of origin.

${ }^{62}$ We showed in section 2.1 that in this case the terms of trade effect will be captured by the first three terms of expression (B).
} 
costs. Exports of automobiles decline by $38 \%$, plant-based fibers $-17 \%,{ }^{63}$ beverages $11 \%$, textiles $-7 \%$, apparel by $-7 \%$, electronics $-5 \%$, light manufacturing $-4 \%$ (Table $4 \mathrm{~A})$.

Despite the decline in export volumes real output remains almost unchanged (-.1\%) as domestic supply chains deepen and the domestic-oriented industries expand $(0.8 \%)$ (Table 4A). Domestic sales increase as consumers and manufacturing sectors increase their demand for domestic manufactured final and intermediate products. ${ }^{64}$

Demand for labor in the export processing industries declines driving real wages of unskilled and skilled nonfarm workers down by $0.3 \%$ (Table $4 \mathrm{~A}$ ). Skilled and unskilled workers are absorbed by the industries producing for the domestic market. The policy change will not threaten China's rural poor. Real wages of unskilled farm workers remain unchanged while real land rents rise by $1 \%{ }^{65}$

The fiscal impact of the reform is positive. Tariff revenue as a share of income rises by $25 \%$, while tax revenue grows by $1.3 \%$. The removal of duty drawbacks will lead to a decline in the bilateral trade surplus with North America of around US\$7 billion or 6 percent. ${ }^{66}$ This will ease China's trade-related tensions with the US. ${ }^{67}$

\footnotetext{
${ }^{63}$ The negative impact on exports of plant based fibers illustrates the importance of production sharing in the region.

${ }^{64}$ The contraction of the export processing sectors and the expansion of the domestic industries are amplified in the case of reduced product differentiation between domestic and imported products. See Appendix Table 1.

${ }^{65}$ These results are robust to changes in the elasticities of substitution (see Appendix Table 1).

${ }^{66}$ These results do not change much for larger elasticities of substitution (see Table 3).

${ }^{67}$ China's trade-related tensions with the US are expected to intensify in the post-WTO period. Ianchovichina and Martin (2004) estimate that the bilateral trade surplus with the United States will increase by 10 percent due to reforms associated with China's entry into the WTO and scheduled to take place between 2001 and 2007.
} 


\subsubsection{Impact of completely liberalizing China's manufacturing sector}

Complete liberalization of China's manufacturing sectors ${ }^{68,69}$ leads to a welfare loss of US $\$ 4.8$ billion, mainly because the terms of trade loss of US $\$ 8.8$ billion a year is nearly twice the efficiency gain of the reform (Table 3). The latter as shown in equation (D) is associated with a contraction of the protected domestic-oriented sector, an increase in final import consumption due to lower import prices and an expansion of the export-oriented sectors. ${ }^{70}$ Increasing the substitutability between Chinese and other countries' products reduces the welfare loss mainly because in this case China's export and import expansions are stronger, while the decline in China's export prices is smaller. ${ }^{71}$ The terms of trade loss may be smaller than US $\$ 8.8$ billion because liberalization will encourage not only the export expansion of existing varieties but also the emergence of new varieties (Martin and Manole, 2004).

Domestic consumer prices fall $(-1.5 \%)$ and exports expand $(8.9 \%)$ as export production costs decline (Table 5). Real GDP remains almost unchanged $(0.1 \%)$ because the domestic-oriented sector and domestic intermediate input use contract due to competition from imports (Table 5). The negative effect on the output of firms producing

\footnotetext{
${ }^{68}$ We remove tariffs only on manufactured imports that are subject to heavy duty drawback use (Table 2). Tariffs in the agro-processing industries (processed food, beverages and tobacco) and the industries involved in natural resource extraction are left unchanged. These industries are not heavy users of imported intermediates (Ianchovichina, 2004), and tariffs in the extraction sector are low.

${ }^{69}$ Since the data do not distinguish between imported goods for intermediate use and final use at the border, we in effect reduce tariffs on both thus liberalizing completely trade in manufactured goods. Remembering the notation in section 2 we change $t$ and $t^{M}$ to zero and the discussion in section 2.3 applies.

${ }^{70}$ Even with duty drawbacks the export-oriented sectors face negative effective rates of protection (Table 2).

${ }^{71}$ With a decline in product differentiation by source the demand curve for Chinese exports flattens. This implies smaller price changes and larger quantity changes than in the case of higher degree of product differentiation.
} 
automobiles will be particularly strong since the motor vehicles' sector will enjoy the highest tariffs on manufactured products after $2007 .^{72}$

The export and farm sectors absorb the workers freed by firms serving the domestic market. Real wages and rents rise since the decline in nominal wages will be more than offset by the decline in domestic consumer prices. The reform will be beneficial to the poor because the unskilled workers' real wages rise more than real wages of skilled workers, with real wages of unskilled farm workers and land rents rising the most (Table 5). ${ }^{73}$

The fiscal impact of the reform is insignificant (Table 3). Although tariff revenue as a share of income declines by $92 \%$, tax revenue as a share of income declines by just $4.6 \%$. The decline in tariff revenue is offset by an increase in tax collection revenue as liberalization boosts economic activity in China. The bilateral trade surplus with North America increases by 12 percent.

\subsubsection{Impact of removing duty drawbacks and halving tariffs on manufactures in China}

Unifying China's tariff structure by eliminating duty drawbacks and halving tariff rates on manufactures offers a compromise in which the outcomes are a combination of the results in the previous two cases. China's welfare measure rises by US\$1 billion a year due to improved efficiency. The efficiency gains are a result of two forces acting in opposite directions. On one hand, the removal of duty drawbacks implies a contraction of the export-oriented sectors and an expansion of the domestic-oriented sectors. This reduces welfare. On the other hand, the reduction in tariffs implies an expansion of the exportoriented sector and a contraction of the domestic-oriented sector. This enhances welfare.

\footnotetext{
${ }^{72}$ Although qualitatively the results do not change, the domestic industries' trade expansion and contraction are amplified with the decline in differentiation between domestic and imported products (see Appendix Table 2).

${ }^{73}$ These results are robust to changes in the elasticities of substitution (see Appendix Table 2).
} 
A deterioration in the terms of trade reduces these efficiency gains. However, this decline is smaller than in the case of liberalizing manufactures since the duty drawback removal softens the fall in export prices. Increasing the substitutability between Chinese and other countries' products amplifies the export and import expansion, and consequently the efficiency and welfare gains (Table 3).

Tariff revenue as a share of income falls by $25 \%$ - much less than in the case of completely liberalizing manufactures since duty drawback removal accompanies the tariff cuts. Tax revenue drops by just $1.3 \%$ as liberalization boosts economic activity. China's bilateral surplus with the US increases, but the increase is negligible since the export expansion following this reform is much more modest than the one following the complete liberalization of manufactures.

The duty drawback removal creates incentives for producers to use domestic intermediate inputs, while the tariff cuts encourage them to purchase imported intermediate inputs. The net aggregate effect on domestic intermediate input use is negligible, with substantial variations by sector. The demand for domestically manufactured intermediate inputs of textiles, light manufacturing and electronics increases, but that of domestically produced auto parts and apparel declines since post-WTO protection on these product groups is high. The effect is negligible for metals and petrochemicals (Table 6).

Exports of all sectors but motor vehicles expand as tariffs are halved. Duty drawback removal dampens this export expansion. Duty drawback removal has a negative impact on automobile exports because of the high intensity of imported input use and postreform protection in the sector. ${ }^{74}$

\footnotetext{
${ }^{74}$ The results for motor vehicles need to be interpreted with caution. The tariffs on autos are a combination of tariffs on auto components and cars. The tariffs on the latter are much higher than those on the former. This implies that the negative effect on car exports may not be as strong as the one portrayed here. Ideally we
} 
Real wages and rents rise since the decline in nominal factor prices is more than offset by a decline in domestic consumer prices. The reform does not harm the rural poor because real wages of unskilled farm workers rise more than those of unskilled non-farm workers. Real returns to farm land rise the most suggesting an overall improvement in returns to farming.

\section{Concluding remarks}

Several broad conclusions emerge from this analysis. An increase in the duty drawback has a positive impact on export competitiveness and employment in the export-oriented industries, but could lead to exports with low domestic value added. The welfare effects of duty drawback and trade reform are ambiguous. An increase in the drawback is more likely to be welfare enhancing if the economy is small with negative effective protection on the export processing activities and positive protection on the domestic-oriented activities, high input tariffs and intensity of imported input use in the export-oriented sectors, low initial drawback and low administrative costs and leakages in the tariff collection system. In such an economy liberalizing intermediate good markets can be welfare enhancing if the cost share of the imported input is higher in the export processing than in the import competing sector. This is more likely to be true for lower duty drawback and higher intensity of import use in the export-oriented sector. Liberalizing intermediate input markets is welfare reducing if there is a complete duty drawback in place.

In China duty drawback removal after meeting its WTO commitments will deepen domestic supply chains and improve welfare, but will hurt China's economic efficiency, output growth, export competitiveness in key manufacturing industries and real factor 
incomes. Further reductions in statutory tariffs on manufactured goods could mitigate the negative effects.

A number of caveats are important. The paper offers a comparative static analysis of duty drawback and trade reforms, and therefore may miss potentially important dynamic effects. In the case of China, foreign direct investment rose as foreigners took advantage of drawbacks on both imported intermediate and capital goods used in the production of exports. Foreign investment and future growth in China may be negatively affected by the abolition of duty drawbacks and positively affected by the liberalization of the manufacturing sector. This suggests that we may have overestimated the welfare increases in the first and third scenarios and the welfare loss in the second scenario presented in section $4 .^{75}$ We have abstracted from quality differences between products, economies of scale and imperfect competition. The latter two could be significant both quantitatively and qualitatively (Harris, 1984). Implementing industrial organization features would have complicated the analytical analysis significantly, but in general one could implement these features in the empirical model. The level of aggregation in this paper hides important information on intra-industry trade. Furthermore, this paper does not capture explicitly the emergence of new products after introduction of a duty drawback. This would raise productivity as new activities enter the production possibilities, and reduce the drain on the terms of trade associated with the export expansion. Martin and Manole (2004) show that China's exports of new products exploded after the generalization of duty exemptions in 1986-87.

\footnotetext{
${ }^{75}$ For simplicity we use a static applied trade model in this paper. However, in general one can estimate the impacts of trade and duty drawback reform using a dynamic applied general equilibrium model.
} 


\section{References}

Amiti, M. 2003. “Economic Geography and Wages,” CEPR Discussion Paper No. 4234.

Armington, P. 1969. "A theory of demand for products distinguished by place of production," IMF Staff Papers 16, 159-178.

Bach, C. and Martin, W. 2001. "Would the right tariff aggregator for policy analysis please stand up?” Journal of Policy Modeling 23(6), 621-35.

Balassa. B., et al. 1971. The Structure of Protection in Developing Countries, Baltimore, Maryland, The Johns Hopkins Press.

Borrus, M., Ernst, D. and Haggard, S. 2000. International production networks in Asia: rivalry or riches? London and New York: Routledge.

Brown, D.K. 1987. "Tariffs, the terms of trade, and national product differentiation," Journal of Policy Modeling 9(3), 503-26.

Cadot, O., de Melo, J. and Olarreaga M. 2003. “The Protectionist Bias of Duty Drawbacks: Evidence from MERCOSUR,” Journal of International Economics, 59(1), 161-82.

Cadot, O., de Melo, J. and Olarreaga M. 2004. "Lobbying, counter-lobbying, and the structure of tariff protection in poor and rich countries," mimeo.

Dimaranan, B. and McDougall, R. 2002. Global Trade, Assistance, and Production: The GTAP 5 Data Base. West Lafayette, Ind.: Purdue University, Center for Global Trade Analysis.

Francois, J. and Shiells, C. 1994. "AGE Models of North American Free Trade," in Francois and Shiells (eds.) Modeling Trade Policy: Applied General Equilibrium Assessments of North American Free Trade, Cambridge University Press. 
General Administration of Customs, PRC 2000. China's Customs Statistics (Monthly Exports and Imports), Series No. 136, December, 2000.

Gourevitch, P., Bohn, R. and McKendrick, D. 1997 "Who is us? The nationality of production in the hard disk drive industry," Report 97-01, Data Storage Industry Globalization Project, Graduate School of International Relations and Pacific Studies, University of California, San Diego, March.

Gruen, N. 1999. "Towards a More General Approach to Trade Liberalization," The Economic Record 75, 385-396.

Hannoch, G. 1975. "Production and Demand Models in Direct or Indirect Implicit Additivity," Econometrica 43, 395-419.

Harrison, J. and Pearson, K. 1996. “Computing Solutions for Large General Equilibrium Models Using GEMPACK,” Computational Economics 9(2), 83-127.

Harris, R. 1984. “Applied General Equilibrium Analysis of Small Open Economies with Scale Economies and Imperfect Competition," The American Economic Review 74(5), 1016-32.

Herander, M. 1986. "Export Drawback and the Structure of Protection," Bulletin of Economic Research 38(1), 43-8.

Hinkle, L., Herrou-Aragon, A. and Kubota, K. 2003. "How Far Did Africa's First Generation Trade Reforms Go?" Africa Region Working Paper Series No. 58, World Bank, Washington D.C., June 2003.

Huang, Y. 2003. Selling China: Foreign Direct Investment During the Reform Era, Cambridge: Cambridge University Press.

Hufbauer and Erb 1984. Subsidies in International Trade, Washington, D.C., Institute for International Economics. 
Ianchovichina, E. 2004. "Trade Policy Analysis in the Presence of Duty Drawbacks," World Bank Policy Research Paper No. 3312 and Journal of Policy Modeling 26, $353-371$.

Ianchovichina, E. and Martin, W. 2004. "Economic Impacts of China's Accession to the WTO," World Bank Economic Review 18(1), 3-27.

International Monetary Fund 2002. "The cases for and against tax incentives," IMF Survey, Vol. 31 (11), 182-85, June 10.

Konan, D. and Maskus, K. 2000. "Joint trade liberalization and tax reform in a small open economy: the case of Egypt," Journal of Development Economics 6, 365-392.

Kruger, A. and Rajapatirana, S. 1999. "The World Bank Policies Towards Trade and Trade Policy Reform," World Economy 22(6), 717-740.

Lardy, N. 2002. "Trade Reforms Prior to Entering the WTO," in Lardy (ed.) Integrating China in the Global Economy, Brookings Institution Press, Washington, DC.

Lemoine, F. and Ünal-Kesenci, D. 2004. “Assembly Trade and Technology Transfer: The Case of China," World Development 32(5), 829-850.

Martin, W. and Manole, V. 2004 "China's Emergence as the Workshop of the World," mimeo, the World Bank.

Maruya, T. 2000. "The Electric Appliance and Electronics Industry Clusters in China: Present Status and Future Prospects," China Newsletter 144, 8-20.

McDougall, R., Elbehri, A. and Truong, T. 1998. Global Trade, Assistance and Protection: The GTAP 4 Data Base. Center for Global Trade Analysis, Purdue University.

Michalopoulos, C. 1999. “Trade Policy and Market Access Issues for Developing Countries: Implications for the Millenium Round,” Policy Research Working Paper 2214, The World Bank, Washington, DC. 
Naughton, B. 2000. "China's Trade Regime on the Eve of WTO Accession: Achievements, Limitations, and Implications for the US," Forthcoming in Ted Galen Carpenter and James Dorn, eds. China's Future: Constructive Partner or Emerging Threat? Washington, D.C.: Cato Institute, July 2000.

Panagariya, A. 1992, "Input tariffs, duty drawbacks and tariff reforms," Journal of International Economics 32, 131-147.

Shi, X. 2001. "Empirical Research on Urban-Rural Income Differentials: A Case of China," Working Paper, Peking University, Beijing.

Sicular, T. and Zhao, Y. 2002. "Employment, Earnings and Labor Market Responses in Rural China," Working Paper, Peking University, Beijing, and the University of Western Ontario, London.

Thomas, V., Nash, J. et al. 1991. Best Practices in Trade Policy Reform, A World Bank publication, Oxford University Press.

World Bank 1994. China: Foreign Trade Reform, Washington D.C.

World Bank 1999. World Development Indicators. Washington, D.C.

Wu, C.S. and Chuang, S.C. 1998. "Duty-drawback Mechanisms: The System in Taiwan (China) and Recommendations for Costa Rica," in Nash, J., Takacs, W. (eds.) Trade Policy Reform: Lessons and Implications. World Bank Regional and Sectoral Studies, Washington, DC., p. 189-210.

Zhang, K. and Song, S. 2000. "Promoting exports: the role of inward FDI in China," China Economic Review 11, 385-396. 


\section{Table 1. China's processing trade, ${ }^{*}$ tariff revenue, and average statutory tariffs ${ }^{* *}$}

\begin{tabular}{|c|c|c|c|c|c|c|c|c|c|}
\hline Year & $\begin{array}{c}\text { Total } \\
\text { Exports }\end{array}$ & $\begin{array}{l}\text { Processing } \\
\text { Exports }\end{array}$ & $\begin{array}{c}\text { Share } \\
\%\end{array}$ & $\begin{array}{c}\text { Total } \\
\text { Imports }\end{array}$ & $\begin{array}{l}\text { Processing } \\
\text { Imports }\end{array}$ & $\begin{array}{c}\text { Share } \\
\%\end{array}$ & $\begin{array}{c}\text { Tariff } \\
\text { Revenue }^{* * *}\end{array}$ & Year & $\begin{array}{c}\text { Tariff rate } \\
\%\end{array}$ \\
\hline 1981 & 220 & 11 & 5.0 & 220 & 14 & 6.4 & 14.7 & 1982 & 55.6 \\
\hline 1982 & 223 & 15 & 6.7 & 193 & 20 & 10.4 & 13.3 & 1985 & 43.3 \\
\hline 1983 & 222 & 19 & 8.6 & 214 & 23 & 10.7 & 12.8 & 1988 & 43.7 \\
\hline 1984 & 261 & 29 & 11.1 & 274 & 30 & 10.9 & 16.6 & 1991 & 44.1 \\
\hline 1985 & 274 & 34 & 12.4 & 423 & 41 & 9.7 & 16.3 & 1992 & 42.9 \\
\hline 1986 & 309 & 56 & 18.1 & 429 & 67 & 15.6 & 10.1 & 1993 & 39.9 \\
\hline 1987 & 394 & 88 & 22.3 & 432 & 102 & 23.6 & 8.8 & 1994 & 36.3 \\
\hline 1988 & 475 & 140 & 29.5 & 553 & 147 & 26.6 & 7.5 & 1996 & 23.6 \\
\hline 1989 & 525 & 198 & 37.7 & 591 & 164 & 27.7 & 8.3 & 1997 & 17.6 \\
\hline 1990 & 621 & 255 & 41.1 & 533 & 187 & 35.1 & 6.2 & 2000 & 17.0 \\
\hline 1991 & 719 & 324 & 45.1 & 638 & 250 & 39.2 & 5.5 & 2001 & 16.6 \\
\hline 1992 & 849 & 396 & 46.6 & 806 & 315 & 39.1 & 4.8 & 2007 & 9.8 \\
\hline 1993 & 917 & 443 & 48.3 & 1040 & 364 & 35.0 & 4.3 & & \\
\hline 1994 & 1210 & 570 & 47.1 & 1156 & 476 & 41.2 & 2.8 & & \\
\hline 1995 & 1488 & 737 & 49.5 & 1321 & 584 & 44.2 & 2.6 & & \\
\hline 1996 & 1510 & 843 & 55.8 & 1388 & 623 & 44.9 & 2.6 & & \\
\hline 1997 & 1828 & 996 & 54.5 & 1424 & 702 & 49.3 & 2.7 & & \\
\hline 1998 & 1837 & 1045 & 56.9 & 1402 & 686 & 48.9 & 2.7 & & \\
\hline 1999 & 1949 & 1109 & 56.9 & 1657 & 736 & 44.4 & 4.1 & & \\
\hline 2000 & 2492 & 1376 & 55.2 & 2251 & 926 & 41.1 & 4.0 & & \\
\hline
\end{tabular}

"Source: General Administration of Customs, PRC (2000). Unless noted otherwise all numbers are in US\$ million. The data for processing imports exclude the value of equipment provided by foreign firms to Chinese firms engaged in processing contracts. These amounts in the latter half of the 1990s were usually between $\$ 1$ billion and $\$ 1.5$ billion annually.

${ }^{* *}$ Source: Lardy (2002) from 1982 to 1991 ; World Bank (1999, p.340) from 1992 to 1998; Ianchovichina and Martin (2004) from 1999 to 2007; post accession average tariff based on China's final WTO offer. These tariff rates are calculated on an un-weighted basis.

${ }^{* * *}$ Source: Lardy (2002). Tariff revenue is a percentage of the value of imports. 
Table 2. China's ERPs and statutory tariffs on manufactured imports in 2007

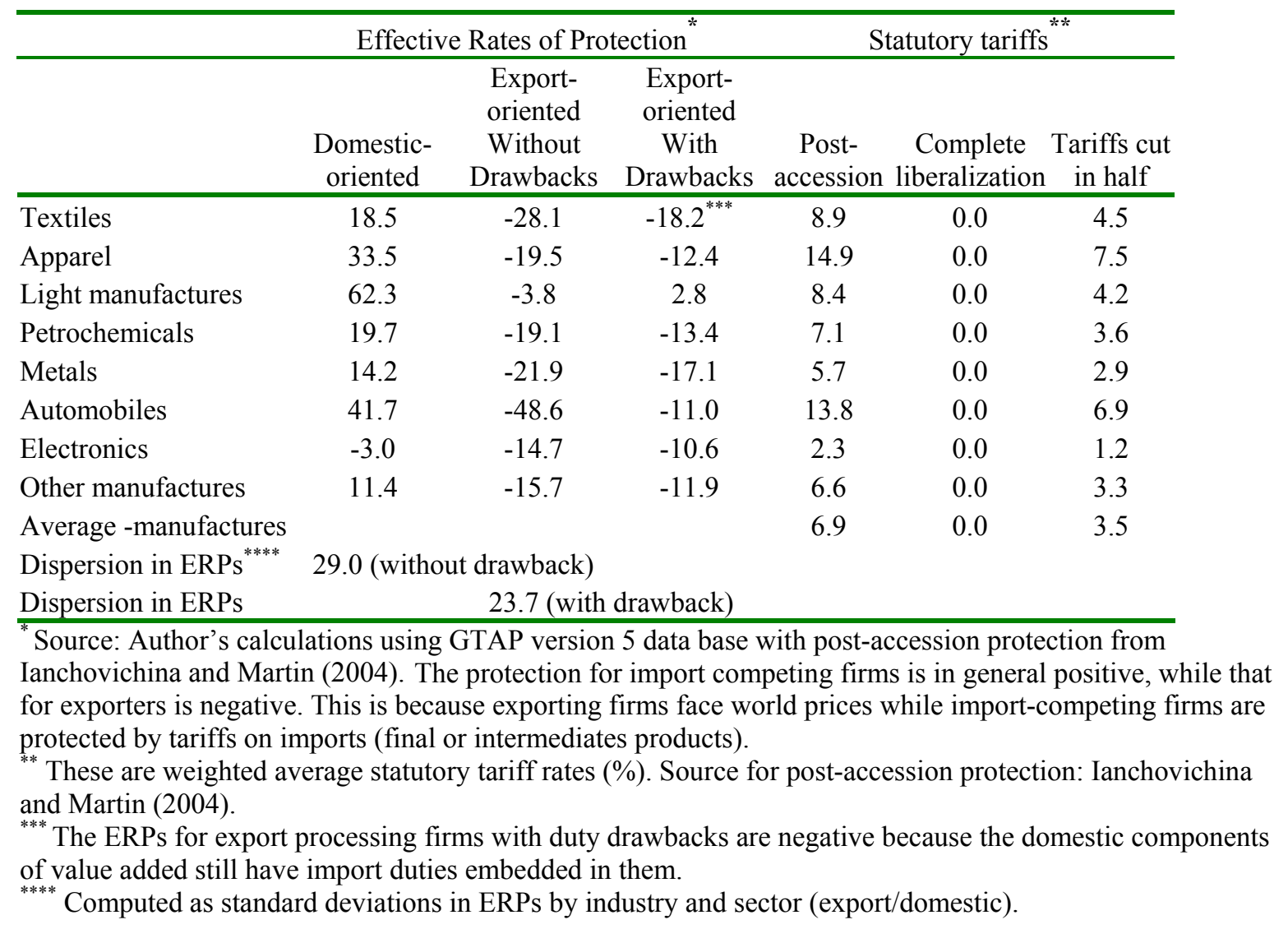


Table 3. Welfare Effects of China's Post-WTO Reform Options

\begin{tabular}{lccc}
\hline & $\begin{array}{c}\text { Removing } \\
\text { duty } \\
\text { drawbacks }\end{array}$ & $\begin{array}{c}\text { Removing tariffs } \\
\text { on manufactured } \\
\text { imports }\end{array}$ & $\begin{array}{c}\text { Removing duty } \\
\text { drawbacks and } \\
\text { halving tariffs on } \\
\text { manufactured } \\
\text { imports }\end{array}$ \\
\hline Scenario & $5.5(4.9)^{*}$ & $-8.8(-8.7)$ & $-1.2(-1.4)$ \\
\hline Terms of trade effect & $0.6(0.5)$ & $-0.8(-0.8)$ & $0.0(-0.1)$ \\
$(+) \Delta$ in world prices & $4.1(3.8)$ & $-6.4(-6.3)$ & $-0.9(-1.0)$ \\
$(+) \Delta$ in export prices & $-0.8(-0.7)$ & $1.6(1.6)$ & $0.3(0.3)$ \\
$(-) \Delta$ in import prices & $-1.7(-2.3)$ & $4.0(5.1)$ & $2.2(3.0)$ \\
Efficiency allocation effect & $-0.2(-0.2)$ & $-0.1(-0.2)$ & $-0.2(-0.2)$ \\
$(+) \Delta$ in factor employment & $-1.5(-2.1)$ & $4.1(5.3)$ & $2.4(3.2)$ \\
$(+) \Delta$ in imports & $3.8(2.6)$ & $-4.8(-3.6)$ & $1.0(1.6)$ \\
Total welfare gain $($ EV) & & & $-25 \%(-25 \%)$ \\
\hline Percentage change in: & $25 \%(21 \%)$ & $-92 \%(-92 \%)$ & $-1.3 \%(-1.3 \%)$ \\
Tariff revenue as a share of income & $1.3 \%(0.8 \%)$ & $-4.6 \%(-4.6 \%)$ & $2 \%(4 \%)$ \\
Tax revenue as a share of income & $-6 \%(-8 \%)$ & $12 \%(18 \%)$ &
\end{tabular}

Source: Author's simulations with the applied general equilibrium model in section 3. Savings due to reduced fraud related to export processing and customs administration costs are negligible (see section 4.1.2) and therefore are not included here.

Note: All numbers in the tables are in 1997 US\$ billion.

* Numbers in parenthesis are results from simulations with the applied general equilibrium model in section 3 and doubled elasticities of substitution between domestic and imported products, and imports by source. 
Table 4A. Economic Impacts of Removing Duty Drawbacks in China

\begin{tabular}{|c|c|c|c|c|c|c|c|}
\hline & $\begin{array}{c}\text { Exports } \\
\%\end{array}$ & $\begin{array}{c}\text { Domestic } \\
\text { sales } \\
\%\end{array}$ & $\begin{array}{c}\text { Output } \\
\%\end{array}$ & $\begin{array}{c}\text { Employ- } \\
\text { ment } \\
\%\end{array}$ & $\begin{array}{c}\text { Domestic } \\
\text { intermediate } \\
\text { use } \\
\%\end{array}$ & $\begin{array}{c}\text { Imports } \\
\%\end{array}$ & $\begin{array}{l}\text { Elasticity of } \\
\text { substitution }\end{array}$ \\
\hline Rice & 1.5 & 0.2 & 0.2 & 0.2 & 0.1 & -0.7 & 4.4 \\
\hline Wheat & -2.4 & 0.7 & 0.7 & 0.8 & 0.7 & -3.3 & 4.4 \\
\hline Feedgrains & -1.9 & 0.2 & 0.2 & 0.2 & 0.2 & -2.7 & 4.4 \\
\hline Vegetables and fruits & -0.6 & 0.2 & 0.2 & 0.3 & 0.2 & 1.4 & 4.4 \\
\hline Oilseeds & -0.5 & 0.5 & 0.5 & 0.6 & 0.5 & -0.6 & 4.4 \\
\hline Sugar & 0.3 & 0.6 & 0.6 & 0.7 & 0.5 & -0.9 & 4.4 \\
\hline Plant based fibers & -17.0 & 3.2 & 3.2 & 3.5 & 3.2 & -8.0 & 4.4 \\
\hline Livestock \& meat & -1.2 & 0.1 & 0 & 0.1 & -0.1 & 8.1 & 5.0 \\
\hline Dairy & -1.4 & 2.6 & 2.5 & 2.7 & 2.5 & -15.3 & 4.4 \\
\hline Other food & -1.2 & 0.6 & 0.3 & 0.3 & 0.4 & -2.0 & 4.4 \\
\hline Beverages \& tobacco & -10.5 & 2.4 & 1.3 & 1.3 & 1.4 & -2.4 & 6.2 \\
\hline Extractive industries & -3.3 & 0.5 & 0.5 & 0.6 & 0.5 & 0.0 & 5.6 \\
\hline Textiles & -7.3 & 4.2 & 1.3 & 1.4 & 4.1 & -11.7 & 4.4 \\
\hline Apparel & -7.2 & 5.7 & -4.6 & -4.5 & 4.2 & -8.5 & 8.8 \\
\hline Light manufacturing & -4.4 & 6.8 & -0.2 & -0.1 & 6.4 & -18.7 & 8.8 \\
\hline Petrochemical industry & -2.6 & 0.8 & 0.6 & 0.5 & 0.8 & -4.0 & 4.1 \\
\hline Metals & -1.3 & 0.8 & 0.6 & 0.5 & 0.8 & -5.9 & 5.6 \\
\hline Autos & -37.9 & 1.7 & -16 & -14.7 & 1.7 & -17.8 & 10.4 \\
\hline Electronics & -4.8 & 1.7 & -1.8 & -1.8 & 1.6 & -3.7 & 5.6 \\
\hline Other manufactures & -3.3 & 1.0 & -0.1 & -0.2 & 1.0 & -5.1 & 5.5 \\
\hline Trade and transport & -2.1 & 0.2 & -0.1 & -0.2 & 0.1 & -1.8 & 3.8 \\
\hline Construction & 1.3 & 0.2 & 0.2 & 0.1 & 0.2 & -1.7 & 3.8 \\
\hline Communication & 1.1 & 0.0 & 0.1 & -0.1 & 0.0 & -2.3 & 3.8 \\
\hline Commercial services & 2.0 & 0.3 & 0.3 & 0.2 & 0.1 & -2.1 & 3.8 \\
\hline Other services & 0.6 & 0.3 & 0.3 & 0.3 & 0.1 & -2.0 & 4.0 \\
\hline Total & -5.6 & 0.8 & -0.1 & 0.0 & 0.7 & -5.7 & \\
\hline Unskilled wages* & -0.2 & \multicolumn{3}{|c|}{ Unskilled non-farm wage } & -0.3 & Land rent & 1.0 \\
\hline Skilled wage & -0.3 & \multicolumn{3}{|c|}{ Unskilled farm wage } & 0 & Capital rent & -0.5 \\
\hline
\end{tabular}

Source: Author's simulations with the empirical model in section 3.

*All wages and rents are given in real terms, i.e. these are percentage changes in wages relative to the CPI. 
Table 4B. Economic Impacts of Removing Duty Drawbacks in China

\begin{tabular}{|c|c|c|c|c|c|c|c|c|}
\hline & $\begin{array}{c}\text { Domestic } \\
\text { consumer } \\
\text { prices } \\
\% \\
\end{array}$ & $\begin{array}{c}\text { World } \\
\text { prices } \\
\%\end{array}$ & $\begin{array}{c}\text { Export } \\
\text { prices } \\
\%\end{array}$ & $\begin{array}{c}\text { Import } \\
\text { prices } \\
\%\end{array}$ & $\begin{array}{l}\text { Net export } \\
\text { share } \\
\text { (SX-SM) }\end{array}$ & $\begin{array}{l}\text { World } \\
\text { price } \\
\text { effect }\end{array}$ & $\begin{array}{l}\text { Export } \\
\text { price } \\
\text { effect }\end{array}$ & $\begin{array}{l}\text { Import } \\
\text { price } \\
\text { effect }\end{array}$ \\
\hline Rice & -0.4 & 0.0 & -0.2 & -0.1 & 0.00 & 0.000 & 0.000 & 0.000 \\
\hline Wheat & -0.1 & -0.1 & 0.2 & -0.1 & 0.00 & 0.000 & 0.000 & 0.000 \\
\hline Feedgrains & -0.1 & 0.0 & 0.3 & -0.1 & 0.00 & 0.000 & 0.000 & 0.000 \\
\hline Vegetables and fruits & -0.3 & 0.0 & 0.0 & -0.1 & 0.00 & 0.000 & 0.000 & 0.000 \\
\hline Oilseeds & -0.1 & 0.0 & 0.0 & 0.0 & -0.01 & 0.000 & 0.000 & 0.000 \\
\hline Sugar & -0.2 & 0.0 & -0.1 & -0.1 & 0.00 & 0.000 & 0.000 & 0.000 \\
\hline Plant based fibers & -0.1 & -0.1 & 1.9 & -0.1 & 0.00 & 0.000 & 0.000 & 0.000 \\
\hline Livestock \& meat & -0.3 & 0.0 & 0.0 & -0.1 & 0.00 & 0.000 & 0.000 & 0.000 \\
\hline Dairy & -0.2 & -0.1 & 0.1 & -0.1 & 0.00 & 0.000 & 0.000 & 0.000 \\
\hline Other food & -0.3 & 0.0 & 0.1 & 0.0 & 0.00 & 0.000 & 0.002 & 0.000 \\
\hline Beverages \& tobacco & -0.3 & 0.0 & 1.1 & -0.1 & -0.04 & 0.000 & 0.005 & -0.002 \\
\hline Extractive industries & -0.1 & -0.1 & 0.3 & -0.1 & -0.07 & 0.004 & 0.000 & 0.000 \\
\hline Textiles & -0.3 & 0.2 & 1.3 & -0.1 & -0.05 & -0.007 & 0.085 & -0.037 \\
\hline Apparel & -0.3 & 0.6 & 1.1 & 0.0 & 0.13 & 0.074 & 0.087 & -0.016 \\
\hline Light manufacturing & -0.4 & 0.2 & 0.6 & -0.1 & 0.05 & 0.013 & 0.024 & -0.005 \\
\hline Petrochemical industry & -0.4 & 0.0 & 0.3 & -0.1 & -0.09 & 0.003 & 0.023 & -0.013 \\
\hline Metals & -0.5 & -0.1 & 0.1 & -0.1 & -0.03 & 0.001 & 0.006 & -0.006 \\
\hline Autos & -0.4 & 0.1 & 5.8 & -0.1 & 0.00 & -0.001 & 0.187 & -0.008 \\
\hline Electronics & -0.3 & 0.0 & 0.5 & -0.1 & 0.01 & 0.000 & 0.069 & -0.010 \\
\hline Other manufactures & -0.5 & 0.0 & 0.3 & -0.1 & 0.09 & -0.003 & 0.101 & -0.018 \\
\hline Trade and transport & -0.6 & -0.1 & 0.2 & -0.1 & 0.02 & 0.003 & 0.018 & -0.001 \\
\hline Construction & -0.6 & -0.1 & -0.2 & -0.1 & 0.00 & 0.000 & 0.000 & 0.000 \\
\hline Communication & -0.7 & -0.1 & -0.2 & -0.1 & 0.00 & 0.000 & 0.000 & 0.000 \\
\hline Commercial services & -0.7 & -0.1 & -0.3 & -0.1 & 0.00 & 0.000 & -0.002 & 0.000 \\
\hline Other services & -0.6 & -0.1 & -0.1 & -0.1 & -0.01 & 0.000 & 0.000 & 0.000 \\
\hline Total & -0.4 & 0 & 0.7 & -0.1 & & 0.087 & 0.605 & -0.116 \\
\hline
\end{tabular}

Source: Author's simulations with the empirical model in section 3. 
Table 5. Economic Impacts of Removing Tariffs on Manufactured Imports in China

\begin{tabular}{|c|c|c|c|c|c|c|c|}
\hline & $\begin{array}{c}\text { Exports } \\
\%\end{array}$ & $\begin{array}{c}\text { Domestic } \\
\text { sales } \\
\%\end{array}$ & $\begin{array}{c}\text { Output } \\
\%\end{array}$ & $\begin{array}{c}\text { Employ- } \\
\text { ment } \\
\%\end{array}$ & $\begin{array}{c}\text { Domestic } \\
\text { intermediate } \\
\text { use } \\
\%\end{array}$ & $\begin{array}{c}\text { Imports } \\
\%\end{array}$ & $\begin{array}{c}\text { Domestic } \\
\text { Consumer } \\
\text { prices } \\
\%\end{array}$ \\
\hline Rice & 4.6 & 0.1 & 0.2 & 0.2 & 0.2 & -3.3 & -0.7 \\
\hline Wheat & 2.8 & 0.7 & 0.7 & 0.7 & 0.7 & -0.9 & -0.4 \\
\hline Feedgrains & 2.6 & 0.1 & 0.2 & 0.2 & 0.1 & -1.7 & -0.1 \\
\hline Vegetables and fruits & 3.7 & 0.1 & 0.1 & 0.1 & 0.3 & -2.6 & -0.7 \\
\hline Oilseeds & 2.0 & 0.6 & 0.6 & 0.7 & 0.6 & -0.1 & -0.3 \\
\hline Sugar & 3.5 & 0.5 & 0.9 & 1.0 & 0.4 & -1.3 & -0.5 \\
\hline Plant based fibers & 8.1 & 0.5 & 0.5 & 0.5 & 0.4 & -1.9 & -0.8 \\
\hline Livestock \& meat & 4.4 & -0.1 & 0.0 & 0.1 & 0.2 & -2.9 & -0.5 \\
\hline Dairy & 4.6 & 1.1 & 1.2 & 1.3 & 1.1 & 0.8 & -0.5 \\
\hline Other food & 5.3 & 0.5 & 1.1 & 1.2 & 0.5 & -2.9 & -0.6 \\
\hline Beverages \& tobacco & 9.3 & 3.0 & 3.6 & 3.5 & 1.0 & -3.7 & -0.5 \\
\hline Extractive industries & 7.2 & 0.0 & 0.0 & 0.0 & 0.0 & -5.2 & -0.9 \\
\hline Textiles & 8.2 & -2.5 & 0.2 & 0.0 & -2.0 & 5.9 & -4.8 \\
\hline Apparel & 8.9 & -35.4 & -0.1 & -0.6 & -8.1 & 53.9 & -7.9 \\
\hline Light manufacturing & 8.2 & -6.0 & 2.8 & 2.6 & -0.6 & 21.1 & -3.8 \\
\hline Petrochemical industry & 7.8 & -2.8 & -2.0 & -2.1 & -2.6 & 13.7 & -2.1 \\
\hline Metals & 12.0 & -2.6 & -1.2 & -1.2 & -2.6 & 14.0 & -1.8 \\
\hline Autos & 5.8 & -14.9 & -5.7 & -6.3 & -14.8 & 15.8 & -5.9 \\
\hline Electronics & 9.0 & 4.3 & 6.9 & 6.8 & 4.4 & 2.5 & -1.9 \\
\hline Other manufactures & 10.5 & -3.5 & 0.1 & 0.0 & -3.3 & 16.9 & -2.2 \\
\hline Trade and transport & 6.2 & 0.0 & 0.6 & 0.6 & 0.0 & -4.3 & -1.0 \\
\hline Construction & 9.2 & 0.0 & 0.0 & 0.0 & 0.0 & -5.5 & -1.4 \\
\hline Communication & 7.1 & -0.2 & 0.1 & 0.1 & -0.1 & -5.1 & -1.2 \\
\hline Commercial services & 6.8 & -0.1 & 0.1 & 0.1 & 0.1 & -4.1 & -1.0 \\
\hline Other services & 8.3 & -0.5 & -0.4 & -0.4 & -0.2 & -5.1 & -1.2 \\
\hline Total & 8.9 & -1.5 & 0.1 & 0.0 & -1.2 & 9.3 & -1.5 \\
\hline Unskilled wages* & 1.1 & Unskille & non-farm v & wage & 1.1 & Land rent & 1.8 \\
\hline Skilled wage & 0.9 & Unskill & d farm wage & & 1.3 & Capital rent & 1.1 \\
\hline
\end{tabular}

Source: Author's simulations with the empirical model in section 3.

*All wages and rents are given in real terms, i.e. these are percentage changes in wages relative to the CPI. 
Table 6. Economic Impacts of Removing Duty Drawbacks and Halving Tariffs on Manufactured Imports in China

\begin{tabular}{|c|c|c|c|c|c|c|c|}
\hline & $\begin{array}{c}\text { Exports } \\
\%\end{array}$ & $\begin{array}{c}\text { Domestic } \\
\text { sales } \\
\%\end{array}$ & $\begin{array}{c}\text { Output } \\
\%\end{array}$ & $\begin{array}{c}\text { Employ- } \\
\text { ment } \\
\%\end{array}$ & $\begin{array}{c}\text { Domestic } \\
\text { intermediate } \\
\text { use } \\
\% \\
\end{array}$ & $\begin{array}{c}\text { Imports } \\
\%\end{array}$ & $\begin{array}{c}\text { Domestic } \\
\text { Consumer } \\
\text { prices } \\
\%\end{array}$ \\
\hline Rice & 2.8 & 0.2 & 0.2 & 0.2 & 0.2 & -2.0 & -0.5 \\
\hline Wheat & 1.1 & 0.5 & 0.5 & 0.6 & 0.5 & -0.4 & -0.2 \\
\hline Feedgrains & -0.1 & 0.2 & 0.2 & 0.3 & 0.2 & -0.8 & -0.1 \\
\hline Vegetables and fruits & 1.1 & 0.2 & 0.2 & 0.3 & 0.3 & -1.1 & -0.4 \\
\hline Oilseeds & 0.6 & 0.5 & 0.5 & 0.6 & 0.5 & 0.1 & -0.2 \\
\hline Sugar & 1.7 & 0.5 & 0.6 & 0.7 & 0.4 & -0.6 & -0.3 \\
\hline Plant based fibers & 0.3 & 1.0 & 1.0 & 1.1 & 1.0 & -0.9 & -0.4 \\
\hline Livestock \& meat & 2.2 & 0.1 & 0.2 & 0.2 & 0.2 & -1.4 & -0.3 \\
\hline Dairy & 2.7 & 0.6 & 0.7 & 0.7 & 0.6 & -0.6 & -0.4 \\
\hline Other food & 3.0 & 0.5 & 0.8 & 0.9 & 0.4 & -1.7 & -0.4 \\
\hline Beverages \& tobacco & 4.5 & 2.2 & 2.4 & 2.3 & 0.7 & -2.3 & -0.4 \\
\hline Extractive industries & 1.8 & 0.2 & 0.2 & 0.3 & 0.2 & -2.5 & -0.5 \\
\hline Textiles & 0.3 & 0.8 & 0.7 & 0.6 & 1.0 & -3.4 & -2.5 \\
\hline Apparel & 0.3 & -14.3 & -2.6 & -2.9 & -1.7 & 21.0 & -3.8 \\
\hline Light manufacturing & 1.1 & 0.7 & 1.0 & 0.9 & 3.0 & -0.7 & -1.9 \\
\hline Petrochemical industry & 2.4 & -0.9 & -0.7 & -0.8 & -0.8 & 4.4 & -1.2 \\
\hline Metals & 4.9 & -0.9 & -0.3 & -0.4 & -0.9 & 3.6 & -1.1 \\
\hline Autos & -18.8 & -6.4 & -11.9 & -11.6 & -6.3 & -2.6 & -3.0 \\
\hline Electronics & 1.7 & 2.9 & 2.2 & 2.2 & 2.9 & -0.7 & -1.1 \\
\hline Other manufactures & 3.1 & -1.2 & -0.1 & -0.1 & -1.1 & 5.3 & -1.3 \\
\hline Trade and transport & 2.7 & 0.1 & 0.3 & 0.3 & 0.1 & -2.9 & -0.8 \\
\hline Construction & 5.0 & 0.2 & 0.2 & 0.1 & 0.2 & -3.5 & -1.0 \\
\hline Communication & 3.9 & -0.1 & 0.1 & 0.0 & -0.1 & -3.6 & -0.9 \\
\hline Commercial services & 4.5 & 0.1 & 0.2 & 0.1 & 0.1 & -3.0 & -0.8 \\
\hline Other services & 4.3 & 0.0 & 0.0 & 0.0 & 0.0 & -3.4 & -0.9 \\
\hline Total & 1.3 & -0.3 & 0.1 & 0.0 & -0.2 & 1.4 & -0.9 \\
\hline Unskilled wages $^{*}$ & 0.4 & \multicolumn{3}{|c|}{ Unskilled non-farm wage } & 0.3 & Land rent & 1.5 \\
\hline Skilled wage & 0.3 & \multicolumn{3}{|c|}{ Unskilled farm wage } & 0.7 & Capital rent & 0.2 \\
\hline
\end{tabular}

Source: Author's simulations with the empirical model in section 3.

*All wages and rents are given in real terms, i.e. these are percentage changes in wages relative to the CPI. 


\section{Appendix}

Appendix Table 1. Sensitivity analysis in the Case of Removing Duty Drawbacks

\begin{tabular}{|c|c|c|c|c|c|c|c|}
\hline & $\begin{array}{c}\text { Exports } \\
\%\end{array}$ & $\begin{array}{c}\text { Domestic } \\
\text { sales } \\
\%\end{array}$ & $\begin{array}{c}\text { Output } \\
\%\end{array}$ & $\begin{array}{c}\text { Employ- } \\
\text { ment } \\
\%\end{array}$ & $\begin{array}{c}\text { Domestic } \\
\text { intermediate } \\
\text { use } \\
\% \\
\end{array}$ & $\begin{array}{c}\text { Imports } \\
\%\end{array}$ & $\begin{array}{c}\text { Domestic } \\
\text { Consumer } \\
\text { prices } \\
\%\end{array}$ \\
\hline Rice & 2.1 & 0.2 & 0.2 & 0.2 & 0.2 & -1.0 & -0.4 \\
\hline Wheat & -3.8 & 0.9 & 0.9 & 1.0 & 0.9 & -4.3 & -0.1 \\
\hline Feedgrains & -2.7 & 0.1 & 0.1 & 0.2 & 0.1 & -3.5 & -0.1 \\
\hline Vegetables and fruits & -0.9 & 0.2 & 0.2 & 0.3 & 0.2 & 2.3 & -0.2 \\
\hline Oilseeds & -1.0 & 0.6 & 0.6 & 0.7 & 0.6 & -0.9 & -0.1 \\
\hline Sugar & 0.2 & 0.8 & 0.7 & 0.8 & 0.7 & -1.3 & -0.2 \\
\hline Plant based fibers & -24.8 & 4.5 & 4.5 & 4.8 & 4.5 & -9.5 & \\
\hline Livestock \& meat & -1.3 & 0.0 & -0.1 & 0.0 & -0.1 & 14.9 & -0.3 \\
\hline Dairy & -2.7 & 3.7 & 3.6 & 4.0 & 3.7 & -20.6 & -0.1 \\
\hline Other food & -1.6 & 0.7 & 0.4 & 0.4 & 0.5 & -2.9 & -0.3 \\
\hline Beverages \& tobacco & -13.4 & 3.4 & 2.0 & 1.9 & 2.0 & -3.6 & -0.3 \\
\hline Extractive industries & -5.6 & 0.5 & 0.5 & 0.7 & 0.5 & 0.4 & -0.1 \\
\hline Textiles & -9.9 & 6.1 & 2.1 & 2.3 & 6.1 & -16.2 & -0.3 \\
\hline Apparel & -9.6 & 7.9 & -6.1 & -5.9 & 6.0 & -12.1 & -0.3 \\
\hline Light manufacturing & -5.1 & 9.5 & 0.5 & 0.5 & 9.0 & -25.2 & -0.3 \\
\hline Petrochemical industry & -3.5 & 1.2 & 0.8 & 0.7 & 1.2 & -5.7 & -0.4 \\
\hline Metals & -1.5 & 1.2 & 0.9 & 0.9 & 1.2 & -8.3 & -0.5 \\
\hline Autos & -51.0 & 2.5 & -21.4 & -19.7 & 2.5 & -24.3 & -0.4 \\
\hline Electronics & -6.7 & 2.6 & -2.4 & -2.4 & 2.4 & -5.3 & -0.3 \\
\hline Other manufactures & -4.2 & 1.4 & 0.0 & -0.1 & 1.4 & -7.3 & -0.5 \\
\hline Trade and transport & -2.6 & 0.2 & 0.0 & -0.2 & 0.1 & -2.8 & -0.6 \\
\hline Construction & 2.2 & 0.2 & 0.2 & 0.1 & 0.2 & -2.6 & -0.6 \\
\hline Communication & 2.1 & 0.0 & 0.1 & 0.0 & 0.0 & -3.5 & -0.7 \\
\hline Commercial services & 3.3 & 0.3 & 0.4 & 0.3 & 0.2 & -3.1 & -0.7 \\
\hline Other services & 1.2 & 0.3 & 0.3 & 0.3 & 0.1 & -3.1 & -0.6 \\
\hline Total & -7.4 & 1.1 & -0.1 & 0.0 & 1.0 & -7.9 & -0.4 \\
\hline Unskilled wages ${ }^{*}$ & -0.2 & Unskill & non-farm & age & $\begin{array}{ll}-0.3 & \mathrm{I}\end{array}$ & Land rent & 1.1 \\
\hline Skilled wage & -0.3 & Unskil & ed farm wa & & 0.0 & Capital rent & -0.5 \\
\hline
\end{tabular}

Source: Author's simulations with the empirical model in section 3 and doubled elasticities of substitution between domestic and imported products and imports from difference sources.

${ }^{*}$ All wages and rents are given in real terms, i.e. these are percentage changes in wages relative to the CPI. 
Appendix Table 2. Sensitivity analysis in the Case of Removing Tariffs on Manufactures

\begin{tabular}{|c|c|c|c|c|c|c|c|}
\hline & $\begin{array}{c}\text { Exports } \\
\%\end{array}$ & $\begin{array}{c}\text { Domestic } \\
\text { sales } \\
\%\end{array}$ & $\begin{array}{c}\text { Output } \\
\%\end{array}$ & $\begin{array}{c}\text { Employ- } \\
\text { ment } \\
\%\end{array}$ & $\begin{array}{c}\text { Domestic } \\
\text { intermediate } \\
\text { use } \\
\% \\
\end{array}$ & $\begin{array}{c}\text { Imports } \\
\%\end{array}$ & $\begin{array}{c}\text { Domestic } \\
\text { Consumer } \\
\text { prices } \\
\% \\
\end{array}$ \\
\hline Rice & 5.4 & 0.2 & 0.3 & 0.3 & $\begin{array}{ll}3 & 0.3\end{array}$ & -4.2 & -0.6 \\
\hline Wheat & 1.2 & 0.8 & 0.8 & 0.9 & 0.8 & -0.3 & -0.2 \\
\hline Feedgrains & 1.9 & 0.2 & 0.2 & 0.3 & 0.2 & -1.9 & -0.1 \\
\hline Vegetables and fruits & 3.3 & 0.2 & 0.2 & 0.3 & 0.4 & -2.9 & -0.5 \\
\hline Oilseeds & 0.4 & 0.7 & 0.7 & 0.7 & 0.7 & 0.4 & -0.1 \\
\hline Sugar & 3.3 & 0.6 & 0.9 & 1.0 & 0.5 & -1.4 & -0.3 \\
\hline Plant based fibers & 10.4 & 0.7 & 0.7 & 0.8 & 0.6 & -2.4 & -0.7 \\
\hline Livestock \& meat & 3.9 & 0.0 & 0.1 & 0.2 & 0.3 & -2.8 & -0.3 \\
\hline Dairy & 4.7 & 1.3 & 1.3 & 1.5 & 1.3 & 1.6 & -0.3 \\
\hline Other food & 6.5 & 0.7 & 1.4 & 1.6 & 0.6 & -3.5 & -0.5 \\
\hline Beverages \& tobacco & 12.7 & 4.4 & 5.1 & 5.1 & 1.4 & -5.0 & -0.5 \\
\hline Extractive industries & 10.6 & -0.1 & -0.1 & -0.1 & -0.1 & -7.8 & -0.9 \\
\hline Textiles & 12.2 & -3.6 & 0.3 & 0.1 & -2.9 & 8.6 & -4.9 \\
\hline Apparel & 13.0 & -51.2 & 0.1 & -0.8 & -11.4 & 77.4 & -8.5 \\
\hline Light manufacturing & 11.6 & -10.1 & 3.4 & 3.1 & -1.5 & 32.8 & -4.0 \\
\hline Petrochemical industry & 11.5 & -4.4 & -3.2 & -3.2 & -4.2 & 21.1 & -2.1 \\
\hline Metals & 18.1 & -4.2 & -2.0 & -2.0 & -4.1 & 21.6 & -1.8 \\
\hline Autos & 8.6 & -22.3 & -8.6 & -9.6 & -22.1 & 23.7 & -6.1 \\
\hline Electronics & 13.6 & 6.6 & 10.4 & 10.2 & 6.8 & 3.7 & -1.9 \\
\hline Other manufactures & 15.7 & -5.5 & 0.0 & -0.1 & -5.1 & 26.3 & -2.2 \\
\hline Trade and transport & 8.8 & 0.1 & 0.9 & 0.9 & 0.1 & -6.0 & -1.0 \\
\hline Construction & 13.7 & 0.1 & 0.1 & 0.1 & 0.1 & -8.0 & -1.4 \\
\hline Communication & 10.2 & -0.3 & 0.2 & 0.2 & -0.3 & -7.3 & -1.2 \\
\hline Commercial services & 9.6 & -0.1 & 0.2 & 0.2 & 0.1 & -5.8 & -0.9 \\
\hline Other services & 12.0 & -0.4 & -0.3 & -0.4 & -0.1 & -7.2 & -1.1 \\
\hline Total & 13.2 & -2.3 & 0.2 & 0.0 & -1.8 & $\begin{array}{ll}3 & 14.3 \\
\end{array}$ & -1.4 \\
\hline Unskilled wages* & 1.2 & Unskill & non-farm & wage & 1.1 & Land rent & 2.4 \\
\hline Skilled wage & 1.0 & Unski & ed farm was & & 1.5 & Capital rent & 1.1 \\
\hline
\end{tabular}

Source: Author's simulations with the empirical model in section 3 and doubled elasticities of substitution between domestic and imported products and imports from difference sources.

*All wages and rents are given in real terms, i.e. these are percentage changes in wages relative to the CPI. 


\section{Appendix Table 3. Sensitivity analysis in the Case of Removing Duty Drawbacks and Halving}

Tariffs on Manufactures

\begin{tabular}{|c|c|c|c|c|c|c|c|}
\hline & $\begin{array}{c}\text { Exports } \\
\%\end{array}$ & $\begin{array}{c}\text { Domestic } \\
\text { sales } \\
\%\end{array}$ & $\begin{array}{c}\text { Output } \\
\%\end{array}$ & $\begin{array}{c}\text { Employ- } \\
\text { ment } \\
\%\end{array}$ & $\begin{array}{c}\text { Domestic } \\
\text { intermediate } \\
\text { use } \\
\% \\
\end{array}$ & $\begin{array}{c}\text { Imports } \\
\%\end{array}$ & $\begin{array}{c}\text { Domestic } \\
\text { Consumer } \\
\text { prices } \\
\% \\
\end{array}$ \\
\hline Rice & 3.3 & 0.3 & 0.3 & 0.3 & 0.3 & -2.5 & -0.4 \\
\hline Wheat & -0.1 & 0.6 & 0.6 & 0.7 & 0.6 & 0.0 & -0.1 \\
\hline Feedgrains & -1.1 & 0.3 & 0.3 & 0.3 & 0.3 & -0.8 & -0.1 \\
\hline Vegetables and fruits & 0.5 & 0.3 & 0.3 & 0.4 & 0.4 & -1.0 & -0.3 \\
\hline Oilseeds & -0.6 & 0.5 & 0.5 & 0.6 & 0.5 & 0.5 & -0.1 \\
\hline Sugar & 1.5 & 0.6 & 0.7 & 0.8 & 0.5 & -0.7 & -0.2 \\
\hline Plant based fibers & -0.5 & 1.4 & 1.4 & 1.6 & 1.4 & -1.0 & -0.4 \\
\hline Livestock \& meat & 1.9 & 0.2 & 0.2 & 0.3 & 0.3 & -1.2 & -0.2 \\
\hline Dairy & 3.0 & 0.8 & 0.8 & 0.9 & 0.8 & -0.4 & -0.3 \\
\hline Other food & 3.8 & 0.7 & 1.0 & 1.1 & 0.6 & -2.2 & -0.4 \\
\hline Beverages \& tobacco & 6.3 & 3.1 & 3.4 & 3.3 & 0.9 & -3.2 & -0.4 \\
\hline Extractive industries & 2.1 & 0.2 & 0.3 & 0.3 & 0.2 & -3.5 & -0.5 \\
\hline Textiles & 0.8 & 1.2 & 1.1 & 1.0 & 1.5 & -4.7 & -2.5 \\
\hline Apparel & 1.0 & -21.7 & -3.6 & -4.0 & -2.5 & 31.4 & -3.9 \\
\hline Light manufacturing & 1.9 & 0.4 & 1.3 & 1.2 & 4.0 & 0.5 & -1.9 \\
\hline Petrochemical industry & 3.7 & -1.5 & -1.1 & -1.2 & -1.4 & 6.8 & -1.2 \\
\hline Metals & 7.6 & -1.4 & -0.5 & -0.6 & -1.4 & 5.7 & -1.1 \\
\hline Autos & -26.7 & -9.6 & -17.2 & -16.7 & -9.5 & -3.2 & -3.0 \\
\hline Electronics & 2.8 & 4.4 & 3.5 & 3.5 & 4.4 & -1.0 & -1.1 \\
\hline Other manufactures & 5.0 & -1.8 & -0.1 & -0.2 & -1.7 & 8.3 & -1.3 \\
\hline Trade and transport & 4.0 & 0.2 & 0.5 & 0.4 & 0.1 & -4.3 & -0.8 \\
\hline Construction & 7.7 & 0.2 & 0.2 & 0.2 & 0.2 & -5.2 & -0.9 \\
\hline Communication & 6.1 & -0.1 & 0.2 & 0.1 & -0.1 & -5.4 & -0.9 \\
\hline Commercial services & 6.8 & 0.2 & 0.4 & 0.3 & 0.2 & -4.5 & -0.8 \\
\hline Other services & 6.5 & 0.0 & 0.1 & 0.0 & -0.1 & -5.0 & -0.9 \\
\hline Total & 2.1 & -0.5 & 0.1 & 0.0 & -0.3 & 2.4 & -0.9 \\
\hline Unskilled wages ${ }^{*}$ & 0.4 & Unskill & d non-farm & wage & 0.3 & Land rent & 1.8 \\
\hline Skilled wage & 0.3 & Unskil & ed farm was & & 0.7 & Capital rent & 0.2 \\
\hline
\end{tabular}

Source: Author's simulations with the empirical model in section 3 and doubled elasticities of substitution between domestic and imported products and imports from difference sources.

*All wages and rents are given in real terms, i.e. these are percentage changes in wages relative to the CPI. 